\title{
Fleas of black rats (Rattus rattus) as reservoir host of Bartonella spp. in Chile
}

\author{
Lucila Moreno Salas ${ }^{\text {Corresp., } 1}$, Mario Espinoza-Carniglia ${ }^{1}$, Nicol Lizama Schmeisser ${ }^{1}$, L. Gonzalo Torres ${ }^{1,2}{ }^{2}$, María \\ Carolina Silva-de la Fuente ${ }^{3,4}$, Marcela Lareschi $^{5}$, Daniel González-Acuña ${ }^{3}$ \\ 1 Departamento de Zoología, Facultad de Ciencias Naturales y Oceanográficas, Universidad de Concepción, Concepción, Chile \\ 2 Facultad de Ciencias, Programa de Magíster en Ciencias mención Ecología Aplicada, Universidad Austral de Chile, Valdivia, Chile \\ 3 Departamento de Ciencia Animal, Facultad de Ciencias Veterinarias, Laboratorio de Parásitos y Enfermedades de Fauna Silvestre, Universidad de \\ Concepción, Chillán, Chile \\ 4 Facultad de Medicina Veterinaria, Universidad San Sebastián, Concepción, Chile \\ 5 Centro de Estudios Parasitológicos y de Vectores CEPAVE (CONICET CCT-La Plata-UNLP), La Plata, Argentina \\ Corresponding Author: Lucila Moreno Salas \\ Email address: lumoreno@udec.cl
}

Background. Rattus rattus is a widely distributed, invasive species that presents an important role in disease transmission, either directly or through vector arthropods such as fleas. These black rats can transmit a wide variety of pathogens, including bacteria of the genus Bartonella, which can cause diseases in humans and animals. In Chile, no data are available identifying fleas from synanthropic rodents as Bartonella vectors. The aim of this study was to investigate the prevalence of Bartonella spp. in the fleas of $R$. rattus in areas with different climate conditions and featuring different human population densities.

Methods. In all, 174 fleas collected from $261 R$. rattus captured from 30 localities with different human densities (cities, villages, and wild areas) across five hydrographic zones of Chile (hyper-arid, arid, semiarid, sub-humid, and hyper-humid) were examined. Bartonella spp. presence was determined through polymerase chain reaction, using glt $A$ and $r p o B$ genes, which were concatenated to perform a similarity analysis with BLAST and phylogenetic analysis.

Results. Overall, 15 fleas species were identified; Bartonella gltA and rpoB fragments were detected in $21.2 \%$ (37/174) and 19.5\% (34/174) of fleas, respectively. Ten of the 15 fleas species found were positive for Bartonella DNA. Leptopsylla segnis was the most commonly collected flea species $(n=55)$, and it also presented a high prevalence of Bartonella DNA $(P \%=34.5 \%)$. The highest numbers of fleas of this species were collected in villages of the arid zone. There were no seasonal differences in the prevalence of Bartonella DNA. The presence of Bartonella DNA in fleas was recorded in all hydrographic areas, and the arid zone presented the highest prevalence of this species. Regarding areas with different human densities, the highest prevalence was noted in the villages $(34.8 \% \mathrm{glt} A$ and $31.8 \% \mathrm{rpoB})$, followed by cities $(14.8 \% \mathrm{~g} / \mathrm{tA}$ and $11.1 \% \mathrm{rpoB})$ and wild areas $(7.4 \% \mathrm{~g} / \mathrm{tA}$ and $14.8 \% \mathrm{rpoB})$. The BLAST analysis showed a high similitude ( $>96 \%$ ) with four uncharacterized Bartonella genotypes and with two species with zoonotic potential: $B$. mastomydis and $B$. tribocorum. The phylogenetic analysis showed a close relationship with $B$. elizabethae and $B$. tribocorum. This is the first study to provide evidence of the presence of Bartonella in fleas of $R$. rattus in Chile, indicating that the villages and arid zone correspond to areas with higher infection risk. 


\section{Fleas of black rats (Rattus rattus) as reservoir host of}

2 Bartonella spp. in Chile

3

4

5

6

Lucila Moreno Salas ${ }^{1}$, Mario Espinoza-Carniglia ${ }^{1}$, Nicol Lizama Schmeisser ${ }^{1}$, L. Gonzalo Torres

Fuentes $^{1,2}$, Carolina Silva-de La Fuente ${ }^{3,4}$, Marcela Lareschi ${ }^{5}$, Daniel González-Acuña ${ }^{3}$

1 Departamento de Zoología, Facultad de Ciencias Naturales y Oceanográficas, Universidad de Concepción, Concepción, Chile

2 Programa de Magíster en Ciencias mención Ecología Aplicada, Facultad de Ciencias, Universidad Austral de Chile, Valdivia, Chile

3 Departamento de Ciencia Animal, Laboratorio de Parásitos y Enfermedades de Fauna Silvestre, Facultad de Ciencias Veterinarias, Universidad de Concepción, Chillán, Chile 4 Facultad de Medicina Veterinaria, Universidad San Sebastián, Lientur 1457, Concepción 4080871, Chile 5 Centro de Estudios Parasitológicos y de Vectores CEPAVE (CONICET CCT-La Plata-UNLP), La Plata, Argentina

Corresponding Author:

Lucila Moreno Salas ${ }^{1}$

Barrio Universitario s/n, Concepción, Región del Biobío, 4030000, Chile

Email address: lumoreno@udec.cl

\section{Abstract}

Background. Rattus rattus is a widely distributed, invasive species that presents an important role in disease transmission, either directly or through vector arthropods such as fleas. The fleas can transmit a wide variety of pathogens, including bacteria of the genus Bartonella, which can cause diseases in humans and animals. In Chile, no data are available identifying fleas from synanthropic rodents as Bartonella vectors. The aim of this study was to investigate the prevalence of Bartonella spp. in the fleas of $R$. rattus in areas with different climate conditions and featuring different human population densities.

Methods. In all, 174 fleas collected from 261 R. rattus captured from 19 localities with different human densities (cities, villages, and wild areas) across five hydrographic zones of Chile (hyperarid, arid, semi-arid, sub-humid, and hyper-humid) were examined. Bartonella spp. presence was determined through polymerase chain reaction, using gltA and rpoB genes, which were concatenated to perform a similarity analysis with BLAST and phylogenetic analysis.

Results. Overall, 15 fleas species were identified; Bartonella glt $A$ and $r p o B$ fragments were detected in $21.2 \%(37 / 174)$ and $19.5 \%$ (34/174) of fleas, respectively. Ten of the 15 fleas species found were positive for Bartonella DNA. Leptopsylla segnis was the most commonly collected flea species $(\mathrm{n}=55)$, and it also presented a high prevalence of Bartonella DNA $(\mathrm{P} \%=34.5 \%)$. The highest numbers of fleas of this species were collected in villages of the arid zone. There were no seasonal differences in the prevalence of Bartonella DNA. The presence of Bartonella DNA in fleas was recorded in all hydrographic areas, and the arid zone presented the highest 
prevalence of this species. Regarding areas with different human densities, the highest prevalence was noted in the villages $(34.8 \% \mathrm{glt} A$ and $31.8 \% \mathrm{rpoB})$, followed by cities $(14.8 \%$ gltA and $11.1 \%$ rpoB) and wild areas (7.4\% gltA and $14.8 \%$ rpoB). The BLAST analysis showed a high similitude $(>96 \%)$ with four uncharacterized Bartonella genotypes and with two species with zoonotic potential: $B$. mastomydis and B. tribocorum. The phylogenetic analysis showed a close relationship with $B$. elizabethae and $B$. tribocorum. This is the first study to provide evidence of the presence of Bartonella in fleas of $R$. rattus in Chile, indicating that the villages and arid zone correspond to areas with higher infection risk.

Keywords: infection, fleas, molecular epidemiology, infectious diseases, public health

\section{Introduction}

Bartonella spp. are vector-borne bacteria that have been identified in a wide range of mammals (Breitschwerdt, 2017). Among these, rodents are described as important reservoirs of Bartonella (Ying et al., 2002; Favacho et al., 2015; Gonçalves et al., 2016). Of the 45 species named to date, 35 have been registered in rodents and/or fleas, of which 13 have been identified as potentially pathogenic to humans (Chomel et al., 2009; Jiyipong et al., 2014; Alsarraf et al., 2017), and five have been implicated in different infections in humans (Daly et al., 1993; Kosoy et al., 2003; Serratrice et al., 2003; Fenollar, Sire \& Raoult, 2005; Buffet, Kosoy \& VayssierTaussat, 2013).

Although reports of human transmission are not frequent, some recent studies support the possibility that rodent-associated Bartonella species may be responsible for human infections, especially in areas where humans and rats are in close contact; these infections are most prevalent in homeless people and are more likely to be contracted while engaging in outdoor activities (Kosoy et al., 2010; Kosoy et al., 2008; Ying et al., 2012). In several of these infection cases, fleas were recognized as the vectors or potential vectors of these bacteria (Chomel et al., 2009); as such, fleas are believed to play a key role in maintaining the Bartonella species in rodents (Buffet, Kosoy \& Vayssier-Taussat, 2013; Billeter et al., 2014), although the role they could play in human infections is unknown.

Rattus rattus (black rat) has been identified as a Bartonella reservoir in different areas of the world (Ellis et al., 1999; Hsieh et al., 2010; Pangjai et al., 2014; Bai et al., 2009; Gonçalves et al., 2016; Peterson et al., 2017). R. rattus is widely distributed in most areas of the world due to human movement (Krystufek et al., 2016) and it has been catalogued as the most harmful invasive species in the world, as it has caused the extinction and displacement of several species of birds and mammals; it is also considered one of the main disease vectors for humans and wild animals (Banks \& Hughes, 2012; Harris, 2009; Towns, Atkinson \& Daugherty, 2006). The latter fact is due to the rat's close contact with humans, as they live in cities and rural areas, and have been able to colonize wild environments, interacting with native species (Lobos et al., 2005). Thus, the Bartonella species in R. rattus may be the result of a host switching between native species (Ellis et al., 1999). 
83

84

85

86

87

88

89

90

91

92

93

94

95

96

97

98

99

100

101

102

103

104

105

106

107

108

109

110

111

112

113

114

115

116

117

118

119

120

121

122

In Chile, only five Bartonella species have been described in domestic animals and humans: $B$. rochalimae in the human flea Pulex irritans (Pérez-Martínez et al., 2009), B. koehlerae, B. clarridgeiae, and B. henselae in cat blood (Ferrés et al., 2005; Zaror et al., 2002, Müller et al., 2017); these last two species have also been detected in cat fleas (Pérez-Martínez et al., 2009), and no species have been detected in rodents and/or the fleas associated with them. In humans, there are reports of a high prevalence of $B$. henselae in children, veterinarians, and zookeepers (Ferrés et al., 2005; Troncoso et al., 2016), and reports of infection-related diseases with $B$. henselae and B. quintana in people (Uribe et al., 2012; Sandoval et al., 2014; Zepeda et al., 2016; Arce, González \& Madrid, 2017).

Chile presents a contrasting diversity of climates due to its long extension (between -35.675148 to -71.5429688), with regions ranging from deserts to rainforests (CONAMA, 2008). R. rattus has been able to colonize many of these environments (Lobos et al., 2005; Iriarte, 2007), which present seasonal changes that can affect the presence and density of hosts and vectors, and can impact the prevalence of Bartonella (Telfer et al., 2007, Friggens et al., 2010). Due to the close contact that black rats maintain with humans and wild species; the high number of flea species described for rats in Chile (12 species; Beaucournu, Moreno \& González-Acuña, 2014), and how the fleas that parasitize them can act as potential Bartonella vectors; as well as the scarce knowledge that exists about Bartonella in Chile associated with human synanthropic rodents, we investigated the prevalence of Bartonella spp. in $R$. rattus fleas in areas characterized by different human population densities throughout the different hydrographic zones and seasons in Chile.

\section{Materials \& Methods}

\section{Sample localities and rodent-trapping procedure}

This study surveyed rodents and fleas in 30 localities (cities, $n=10$; village, $n=10$; wild areas, $\mathrm{n}=10$ ) of five hydrographic zones (hyper-arid, arid, semi-arid, sub-humid, and hyper-humid, between -20.2167 lat. to -53.1667 lat; Figure 1) of Chile from December 2015 to January 2018. This study took place during austral summer (December to February) and austral winter (July and September), except in the hyper-arid and hyper-humid hydrographic zones, which were visited only in the winter and summer, respectively. The sample localities were chosen based on the following demographic characteristics: 1) City: an urban entity with more than 5,000 inhabitants; 2) Village: an urban entity with a population ranging from 2,001-5,000 inhabitants or between 1,001 and 2,000 people and met the economic activity requirement (INE, 2005); and 3) wild area: a protected area without human settlement; for the latter, permission was requested from the Corporación Nacional Forestal (CONAF N018-2015).

The rodents were captured using live cage traps baited with oats. Each locality was sampled for two consecutive nights. In each sampling locality, the traps were placed in four parallel lines (approximately $100 \mathrm{~m}$ from each other) and each line was equipped with 50 traps (with a distance of $10 \mathrm{~m}$ between each other), with a total sampling effort of 12,000 traps per night. The rodents were removed from the traps according to standard techniques (Mills et al., 1995). Each 
123

124

125

126

127

128

129

130

131

132

133

134

135

136

137

138

139

140

141

142

143

144

145

146

147

148

149

150

151

152

153

154

155

156

157

158

159

160

161

162

animal was identified using the description by Iriarte (2007), anesthetized with ketamine:xylazine (1:1), and euthanized by cervical dislocation (American Veterinary Medical Association, 2013). The carcasses were placed in individual bags with $95 \%$ alcohol and transported to the laboratory. Animal use was conducted in accordance with the protocols for field and laboratory rodent studies (Herbreteau et al., 2011), and the protocols were approved by the Comité de Ética de la Vicerrectoría de Investigación y Desarrollo de la Universidad de Concepción.

\section{Fleas: Sample collection}

Each rodent was placed on a white plastic basin and the fleas were collected immediately in the field. The rodents' fur was thoroughly brushed with a toothbrush and the fleas were collected by hand or with forceps, and stored individually in sterile cryovials with $95 \%$ ethanol. Later, in the laboratory, the carcasses were checked to verify that all fleas had been collected. For each rodent, the total number of fleas extracted was recorded (abundance) and with this data, the mean intensity of infection (the number of fleas collected from all species/number of infested hosts), the mean abundance of infection (the number of collected fleas from all species/total number of hosts), and prevalence (the number of infected hosts) were calculated.

\section{DNA extraction}

For DNA extraction, every flea was washed and cut between the third and fourth abdominal tergites with a sterile scalpel. The material used to handle the fleas was sterilized between each sample. DNA was extracted using a commercial kit (Qiagen $®$, Hilden, Germany) according to the manufacturer's instructions. The incubation time was 5 hours, after which point a final elution step was performed using $200 \mu \mathrm{L}$ of AE buffer and stored at $-20^{\circ} \mathrm{C}$.

Following the DNA extraction, the fleas' exoskeletons were recovered and stored in $96 \%$ ethanol; there were subsequently mounted for fleas' species identification. DNA contamination was monitored by an extraction control using distilled water, every 10 samples.

\section{PCR amplification of gltA and rpoB genes}

The presence of Bartonella was screened using the citrate synthase ( $g l t A)$ and RNA polymerase beta-subunit $(r p o B)$ genes. The primers used for DNA amplification and sequencing in this study were designed from a partial gltA and rpoB gene sequence of B. tribocorum (GenBank code: AM260525.1; Table 1).

For the amplification of the gltA gene fragment, the PCR program was modified with an initial denaturation for 5 minutes at $95^{\circ} \mathrm{C}$, followed by 40 cycles $\left(95^{\circ} \mathrm{C}\right.$ for 30 seconds, $56.2^{\circ} \mathrm{C}$ for 30 seconds, and $72^{\circ} \mathrm{C}$ for 30 seconds), and a final extension step at $72^{\circ} \mathrm{C}$ for 5 minutes. For the $r p o B$ gene, the PCR was started by denaturation for 5 minutes in $95^{\circ} \mathrm{C}$, followed by 40 cycles $\left(95^{\circ} \mathrm{C}\right.$ for 30 seconds, $56.6^{\circ} \mathrm{C}$ for 30 seconds, and $72^{\circ} \mathrm{C}$ for 30 seconds), and a final extension step at $72^{\circ} \mathrm{C}$ for 5 minutes. Reactions were performed in $26 \mu \mathrm{L}$ of mixture containing GoTaq ${ }^{\circledR}$ Green 
163 Master Mix (Promega Corporation, Madison, WI, USA) 2X 12.5 $\mu \mathrm{L}+5.5 \mu \mathrm{L}$ of free ultrapure

164

165

166

167

168

169

170

171

172

173

174

175

176

177

178

179

180

181

182

183

184

185

186

187

188

189

190

191

192

193

194

195

196

197

198

199

200

201

202 water nuclease $+2 \mu \mathrm{L}$ of forward primer $(10 \mu \mathrm{M})+2 \mu \mathrm{L}$ of reverse primer $(10 \mu \mathrm{M})+4 \mu \mathrm{L}$ of DNA sample. Negative controls for the polymerase chain reaction (PCR) consisted of a blank DNA extraction and distilled water was added to the PCR mix instead of DNA. Positive control was the genomic DNA of Bartonella henselae (Vircell Microbiologist, Granada, Spain). PCR products were subjected to electrophoresis on $1 \%$ agarose gel at a voltage of $100 \mathrm{~V}$. Then, the PCR products from positive samples were sequenced by Macrogen Company (Seoul, Korea).

\section{Sequencing, BLAST, and phylogenetic analysis}

The DNA sequences used in this study and the known Bartonella species retrieved from GenBank were aligned using Codon Code Aligner (Codon Code Corporation; Supplementary files 1 and 2). The sequencing data of $g l t A$ and $r p o B$ were concatenated and compared with the sequences of Bartonella available in GenBank using the nucleotide-nucleotide BLAST (blastn) program (see http://www.ncbi.nlm.nih.gov/BLAST/). A substitution saturation test with DAMBE (Xia, 2017) was performed, showing that the sequences were not saturated (Xia et al., 2003; Xia \& Lemey, 2009). We used MEGA7 (Kumar, Stecher \& Tamura, 2015) to calculate the genetic distances between sequences. A tree with Bayesian probabilities was computed using MrBayes 3.2 (Ronquist et al., 2012) based on concatenated gltA (142 bp) and rpoB (95 bp) gene fragments, using Brucella abortus as an outgroup (Accession number, gltA: LIUE01000001.1; rрoB: CP023241.1). The GTR substitution model was used to reconstruct the tree and perform 10,000,000 bootstrap trials. Haplotype diversity (Hd), segregating sites (S), and nucleotide diversity $(\pi)$ were calculated using DNAsp 6. The accession numbers of the GenBank sequences used to reconstruct the tree are detailed in Figure 2.

\section{Mounting fleas}

Fleas were mounted on glass slides using conventional procedures (Hastriter \& Whiting, 2003). Fleas were identified at the species level using the taxonomic keys and the descriptions of Hopkins and Rothschild (1956, 1962, and 1966); Smit (1987); Schramm (1987), Beaucournu, Murua, and Gallardo (1988); Beaucournu and Gallardo (1988); Beaucournu and Kelt (1990); Beaucournu, Moreno, and González-Acuña (2011); Sánchez et al. (2012); and Sánchez and Lareschi (2014). Voucher specimens of each flea species were deposited in the specimen repository of the Museo de Zoología, Universidad de Concepcion, Concepción, Chile (MZUCCCC-46329 to 46336).

\section{Data analysis}

The prevalence ( $\mathrm{P} \%)$, mean abundance (MA), and mean infestation intensity (MI) of fleas was calculated according to Rozsa, Reiczigel, and Majoros (2000) and were compared between seasons, hydrographic zones, and areas with different population densities using chi-squared and Fisher's exact tests to compare prevalence, while a Bootstrap $t$-test with 2,000 replications was used to compare mean abundance and infestation intensity. The Clopper-Pearson test was used

Peer] reviewing PDF | (2019:04:36838:1:1:NEW 21 Jun 2019) 
203 to calculate the confidence interval (CI) for prevalence, and a Bootstrap test was used to

204 calculate the CI for mean intensity and mean abundance. Bartonella prevalence (percentage of

205 infected fleas) was calculated based on the PCR results. The associations between Bartonella

206 infection and hydrographic zone, human density, and season were evaluated using the chi-

207 squared test, and for small sample sizes, F-Fisher was used. A $P$-value less than 0.05 was

208 considered to be statistically significant. Statistical analyses were performed using the

209 Quantitative Parasitology software (QP 3.0; Rozsa, Reiczigel \& Majoros, 2000).

210

211

Nucleotide sequence accession numbers

212 The sequences of Bartonella gene fragments generated in this study were deposited in the NCBI

213 GenBank database under the following accession numbers: gltA: MK720786-MK720800, and

214 гров: MK720801-MK720815.

215

216

\section{Results}

217 A total of 261 R. rattus (summer: $\mathrm{n}=139$; winter: $\mathrm{n}=122$ ) were collected in 21 of the 30 localities (city: $n=149$; village: $n=53$; wild area: $n=59)$ and $31 \%(n=81)$ of the black rats were positive for fleas. A total of 174 fleas were collected (winter: $n=99$; summer: $n=75$ ), representing 15 species from 10 different genera and seven families (Table 2). Ctenoparia jordani Smit, 1955; Neotyphloceras chilensis (Jordan, 1936); Neotyphloceas pardinasi Sánchez \& Lareschi, 2014; Delostichus smiti Jameson \& Fulk, 1977; Tetrapsyllus rhombus Smit, 1955; Plocopsylla wolffsohni (Rothschild, 1909); and Sphinctopsylla ares (Rothschild, 1911) are new records for $R$. rattus in Chile. The MI was 2.18 (range: 1-15) fleas per black rat. In 9 cities, between 1 and 5 species of fleas were collected, in 8 villages between 1 and 4, and in 3 wild areas between 3 and 4 species of fleas. The hydrographic zones (i.e., hyper-arid and hyper-humid zones) demonstrated the lowest richness of flea species, with 1 and 3 species, respectively, while the semi-arid and sub-humid zones presented 8 species each. The flea species Leptopsylla segnis (Schönherr, 1811) ( $\mathrm{n}=55)$ and Nosopsyllus fasciatus (Bosc'd antic 1831) $(\mathrm{n}=45)$ were the most abundant species in villages and cities, respectively, and were not found in wild area. Two species of fleas were found only in wild areas: Delostichus coxalis (Rothschild, 1909) and C. jordani. Hectopsylla sp. and N. chilensis were collected only in villages. Ctenoparia inopinata Rothschild, 1909, D. smiti, and Xenopsylla cheopis Glinkiewicz, 1907 were exclusive to cities. $N$. pardinasi and $S$. ares were found in cities, villages, and wild areas (Table 2). Although the number of captured rodents $(n=149)$ and collected fleas $(n=111)$ was higher in cities than in villages (rodents: $n=53$; fleas: $n=96$ ) and wild areas (rodents: $n=59$; fleas: $n=38$ ), the prevalence of fleas was significantly higher in the villages $(45.3 \%$, chi-squared $=6.679$, df $=2, P=0.035)$, while wild areas (30.5\%) and cities (26.2\%) did not show significant differences (chi-squared $=0.399, \mathrm{df}=1, P=0.528$ ). The mean infestation intensity was higher in villages $(\mathrm{MI}=2.83)$, than in cities $(\mathrm{MI}=2.26)$ and wild areas $(\mathrm{MI}=1.89)$, but no statistically significant differences were found (Bootstrap $P$-value [two-sided] $>0.05$ ). The mean abundance was also 
243

244

245

246

247

248

249

250

251

252

253

254

255

256

257

258

259

260

261

262

263

264

265

266

267

268

269

270

271

272

273

274

275

276

277

278

279

280

281

test $P<0.05$ ), but there were no significant differences between cities and wild areas (Bootstrap $t$ test $P=0.9360$; Table 3).

Seasonally, the prevalence, mean abundance, and mean intensity of fleas were higher in winter $(\mathrm{P} \%=34.4 \%, \mathrm{MA}=0.90, \mathrm{MI}=2.62)$ than in summer $(\mathrm{P} \%=28.1 \%, \mathrm{MA}=0.57, \mathrm{MI}=2.05)$, but no statistically significant differences were found between seasons $(\mathrm{P} \%$ : chi-squared statistic $=1.231, \mathrm{df}=1, P=0.267$; MA: Bootstrap $t$-test $P=0.0870$; MI: Bootstrap $t$-test $P=0.1340$; Table 4). In winter, only prevalence was significantly higher in the villages $(\mathrm{P} \%=57.89 \%, \mathrm{MA}=1.789$, $\mathrm{MI}=3.091)$ than in the cities $(\mathrm{P} \%=28.8 \%, \mathrm{MA}=0.881, \mathrm{MI}=3.059 ; \mathrm{P} \%$ : chi-squared statistic $=5.282, \mathrm{df}=1, P=0.022$; AM: Bootstrap $t$-test $P=0.0755$; MI: Bootstrap $t$-test $P=0.9660)$ and wild areas $(\mathrm{P} \%=31.8 \%, \mathrm{MA}=0.545, \mathrm{MI}=1.714 ; \mathrm{P} \%$ : chi-squared statistic $=3.77, \mathrm{df}=1, P=0.052 ; \mathrm{MA}$ : Bootstrap $t$-test $P=0.0155$; MI: Bootstrap $t$-test $P=0.0360)$. Regarding the hydrographic zones, in winter, the highest prevalence, mean intensity, and mean abundance were found in the arid zone $(\mathrm{P} \%=64.3 \%, \mathrm{MA}=2.79, \mathrm{MI}=4.33)$, and these values were significantly different from those of the sub-humid zone $(\mathrm{P} \%=27.7 \%, \mathrm{MA}=2.78, \mathrm{MI}=1.78 ; \mathrm{P} \%$ : chi-squared statistic $=11.045, \mathrm{df}=1$,

$P=0.001$; MA: Bootstrap $t$-test $P=0.011$; MI: Bootstrap $t$-test $P=0.038$ ), while with the semi-arid zone, the prevalence and mean abundance differed significantly $(\mathrm{P} \%$ : chi-squared statistic $=5.841, \mathrm{df}=1, P=0.016$; MA: Bootstrap $t$-test $P=0.0235$ ), but this was not the case for mean intensity (Bootstrap $t$-test $\mathrm{P}=0.22$ ). There was no significant difference between the sub-humid $(\mathrm{P} \%=27.7 \%, \mathrm{MA}=0.492, \mathrm{MI}=1.78)$ and semi-arid zones $(\mathrm{P} \%=27.8 \%, \mathrm{MA}=0.788, \mathrm{MI}=2.8 ; \mathrm{P} \%$ :

Fisher's exact test $P=1.00$; MA: Bootstrap $t$-test $P=0.467$, MA: Bootstrap $t$-test $P=0.254$ ). In the summer, there were no significant differences in the prevalence (chi-squared statistic $=2.341, \mathrm{df}=2, P=0.310$ ), mean abundance (Bootstrap $t$-test $P=0.077$ ), and mean intensity (Bootstrap $t$-test $P=0.089$ ) of fleas between cities, villages, and wild areas (Table 4 ). The arid zone showed a higher prevalence, mean abundance, and mean intensity $(\mathrm{P} \%=54.8 \%, \mathrm{MA}=1.645$, $\mathrm{MI}=3.00)$ than the semi-arid $(\mathrm{P} \%=23.5 \%, \mathrm{MA}=0.588, \mathrm{MI}=2.51)$ and sub-humid zones $(\mathrm{P} \%=17.9 \%, \mathrm{MA}=0.256, \mathrm{MI}=1.43)$, although it only differed significantly in terms of prevalence with the semi-arid zone $(\mathrm{P} \%$ : chi-squared statistic $=4.373, \mathrm{df}=1, P=0.037$; MA: Bootstrap $t$-test $P=0.045$, MI: Bootstrap $t$-test $P=0.5635)$, and in terms of prevalence and mean abundance with the sub-humid zone $(\mathrm{P} \%$ : chi-squared statistic $=14.833, \mathrm{df}=1, P=0.000$; MA: Bootstrap $t$-test $P=0.0280$, MI: Bootstrap $t$-test $P=0.0605)$. No significant differences were observed in these parameters between the semi-arid and sub-humid zones ( $\mathrm{P} \%$ : Fisher's exact test $P=0.733$, MA: Bootstrap $t$-test $P=0.2545$, MI: Bootstrap $t$-test $P=0.2275$ ).

The Bartonella gltA and rpoB fragment was detected in $21.26 \%(37 / 174)$ and $19.54 \%(34 / 174)$ of the fleas, respectively, collected from 22 different $R$. rattus individuals. Although a higher prevalence of Bartonella was detected using the gltA fragment, this finding was not statistically significant (chi-squared statistic $=0.159, \mathrm{df}=1, P=0.690$ ). Ten of the 15 flea species found were positive for Bartonella. We observed the highest prevalence in Hectopsylla sp. (100\%) and X. cheopis $(63 \%)$, although the number of flea samples collected from these species was low (Table 2). While L. segnis was the most commonly collected flea $(n=55)$, it also presented a high 
282 prevalence of Bartonella DNA ( $\mathrm{glt} A=34.54 \%$ and $r p o B=27.3 \%$ ); the highest numbers of fleas of

283

284

285

286

287

288

289

290

291

292

293

294

295

296

297

298

299

300

301

302

303

304

305

306

307

308

309

310

311

312

313

314

315

316

317

318

319

320

321

this species were collected in villages in the arid zone (Table 2).

The presence of Bartonella DNA in fleas was recorded in all hydrographic areas, but not in all localities. Of the hydrographic zones with more than 20 fleas analyzed, the arid zone had a greater prevalence of Bartonella DNA $(26.1 \% \mathrm{glt} A$ and $28.3 \% \mathrm{rpoB})$ than in the sub-humid zone $(2.5 \% \mathrm{glt} A$ and $r p o B)$ for both genes $(\mathrm{glt} A$ : chi-squared $=10.103, \mathrm{df}=1, P=0.001$; rpoB: chisquared $=11.371, \mathrm{df}=1, P=0.001$ ), whereas with the semi-arid area, the only difference was found in the prevalence with the glt $A$ gene $(4.3 \%$ glt $A$ : chi-squared $=5.111, \mathrm{df}=1, P=0.024 ; 17.4 \%$ rроB: chi-squared: $1.127, \mathrm{df}=1, P=0.288$ ). The prevalence of Bartonella DNA in the semi-arid and sub-humid zones did not differ significantly ( $g l t A$ : Fisher's exact test $P=1.00 ; r p o B$ : Fisher's exact test $P=0.055)$. The highest prevalence was noted in the villages $(34.8 \%$ glt $\mathrm{A}$ and $31.8 \%$ $r p o \mathrm{~B})$, which differed significantly from that in the city $(14.81 \%$; chi-squared $=6.039, \mathrm{df}=1$, $P=0.014)$ and the in the wild area $(7.41 \%$; chi-squared $=7.34, \mathrm{df}=1, P=0.007)$ for the glt $A$ gene, whereas for the $r p o B$ gene, only the villages $(31.82 \%)$ and cities $(11.11 \%)$ were significantly different (chi-squared $=9.6, \mathrm{df}=1, P=0.002$ ). No significant differences were observed between the cities and wild areas (Fisher's exact test $P=0.733$ ), and between the wild areas and villages (chi-squared $=2.82, \mathrm{df}=1, P=0.093$ ). In all, 22 rodents carried fleas that were positive for Bartonella. The fleas positive for Bartonella were extracted from 13 village rodents, 5 city rodents, and 4 wild-area rodents.

No statistically significant differences ( $g l t \mathrm{~A}$ : chi-squared $=3.427, \mathrm{df}=1, P=0.064 ;$ rpoB: chisquared $=2.814, \mathrm{df}=1, P=0.093$ ) were observed in the prevalence of Bartonella DNA in fleas between the winter ( $g l t A: 26.26 \%$; rpoB: $15.15 \%$ ) and summer ( $g l t A: 14.67 \%$; rpoB: $25.33 \%$; Table 4).

The BLAST analyses showed similar findings for eight Bartonella spp. (Table 5). The genetic distances between the findings from GenBank and the sequences obtained in this study are shown in Supplemental file 3. The phylogenetic analysis showed that concatenated $g l t A$ and rрoB sequences could be related to a known Bartonella species (Figure 2). It was found that Bartonella present in the flea species (Hectopsylla sp. and L. segnis) collected from cities and villages in arid zones are closely related to B. coopersplainsensis. Bartonella DNA detected in $X$. cheopis collected only in a city from a hyper-arid zone was closely related to B. mastomydis and $B$. queenslandensis. Bartonella DNA in $N$. fasciatus was closely related to B. tribocorum. Finally, Bartonella detected in N. pardinasi was related to B. mayotimonensis, while that detected in $S$. ares was related to $B$. doshiae. Eight haplotypes were found $(\mathrm{Hd}=0.838, \mathrm{~S}=60$, $\pi=0.095)$.

\section{Discussion}

The presence of Bartonella DNA in R. rattus fleas has not been previously reported in Chile; therefore, this is the first study to report on and document the prevalence of this bacteria in fleas over a large spatial scale $\left(-20^{\circ}\right.$ to $-53^{\circ}$ lat.) covering five hydrographic zones with differences in human density. To our knowledge, this is the first report of the detection of Bartonella spp. in

Peer) reviewing PDF | (2019:04:36838:1:1:NEW 21 Jun 2019) 
322

323

324

325

326

327

328

329

330

331

332

333

334

335

336

337

338

339

340

341

342

343

344

345

346

347

348

349

350

351

352

353

354

355

356

357

358

359

360

361

several flea species: $N$. chilensis, $N$. pardinasi, Neotyphloceras sp., D. coxalis, T. rhombus, $S$. ares, and Hectopsylla sp., all of which parasitize native rodents of Chile. This indicates that $R$. rattus is in contact with wild-rodent populations and can act as a reservoir for and facilitator in the dispersion of these fleas - and in the Bartonella species detected. While the presence of Bartonella in $X$. cheopis, L. segnis, and $N$. fasciatus confirms the findings made by other authors in other parts of the world (Parola et al., 2003; Winoto et al., 2005; Loftis et al., 2006; Reeves et al., 2007; Li et al., 2007; Tsai et al., 2010; Hornok et al., 2015), the Bartonella reported in these three flea species is also new to Chile. Although it cannot be stated that these flea species are competent vectors of Bartonella, as they may have consumed Bartonella-infected blood from a host with bacteremia, their role as vectors of these bacteria cannot be ruled out; as such, future laboratory tests to verify their competence are necessary (Billeter et al., 2008).

The prevalence of Bartonella in the rodent fleas in our study is within the ranges documented by other authors $(2.1 \%-40.5 \%)$, values that vary with respect to the geographical area and flea species analyzed (Loftis et al., 2006; Marie et al., 2006; Li et al., 2007; Bitam et al., 2012; Billeter et al., 2014, Dieme et al., 2015, Lipatova et al., 2015). Bartonella DNA was found in several flea species with variations observed in the infection prevalence of Bartonella detected between flea species (4.2\%-100\%). In five flea species collected from $R$. rattus, Bartonella DNA was not detected, which could be due to the low number of fleas analyzed in these species (between 1 and 4 individuals). However, Bartonella DNA prevalence was high in other species that were not abundant in the sample, such as Hectopsylla sp., X. cheopis, and T. rhombus. Each flea species was collected from a single rodent, which could be infected with Bartonella, which would explain the high prevalence. It is unlikely that finding Bartonella DNA in Hectopsylla sp. would pose a risk to human health, because these fleas are neosomatic and females are semipenetrating (Linardi \& Moreira de Avelar, 2014), they stay attached to the host for long periods of time, representing little chance that it will infect humans. The high prevalence of Bartonella DNA reported in this study for X. cheopis $(63.6 \%)$ would be within the ranges reported for other parts of the world (Billeter et al., 2011: 95\%; Leulmi et al., 2014: 34.7\%; Klangthong et al., 2015: 25.8\%; Billeter et al., 2013: 59.1\%; Dieme et al., 2015: 6.7\%). Xenopsylla cheopis is the most frequently occurring and abundant species to isolate from $R$. rattus (e.g., Loftis et al., 2006; Christou et al., 2010; Guernier et al., 2014), and is associated with the transmission of several pathogens to humans (e.g., the plague, endemic murine typhus, helminth parasites; Farhang-Azad, Traub \& Baqar, 1985; Bitam et al., 2006; Gárate et al., 2011). Several species of Bartonella have been detected in X. cheopis (B. elizabethae, B. grahamii, B. tribocorum, B. rochalimae, B. rattimassiliensis, Bartonella queenslandensis, and Bartonella $\mathrm{sp}$. 1.1C; Billeter et al., 2008; Tsai et al., 2010; Billeter et al., 2011; Dieme et al., 2015), although its competence as a vector has only been determined experimentally for B. elizabethae, which would be eliminated through the feces (McKee et al., 2018). Tetrapsyllus rhombus was another very rare species, but which had a high prevalence of Bartonella DNA; there is no known history of pathogens that this flea species transmits. However, the finding in $R$. rattus provides evidence of the exchange of fleas between wild and introduced species. T. rhombus is widely distributed 
362

363

364

365

366

367

368

369

370

371

372

373

374

375

376

377

378

379

380

381

382

383

384

385

386

387

388

389

390

391

392

393

394

395

396

397

398

399

400

401

in central and southern Chile, parasitizing 13 species of wild rodents of the families Cricetidae, Octodontidae, and Ctenomyidae (Beaucournu, Moreno \& González-Acuña, 2014).

Conversely, fleas that were abundant in R. rattus, such as L. segnis and N. fasciatus, presented significant differences in the prevalence of Bartonella DNA. Few studies have detected Bartonella in L. segnis, with prevalence rates of $0 \%(0 / 174), 3 \%(1 / 37)$, and 10\% (1/10; Loftis et al., 2006; Li et al., 2007, Hornok et al., 2015). Leptopsylla segnis is widely distributed, attributed to the dispersal of its hosts (rats and mice), as a result of human activity. This species is distributed in temperate zones, although in our study, it was distributed from the arid zone to the hyper-humid zone, with the greatest abundance observed in the arid zone. In our study, we did not find the species in wild areas, while there are records in Chile that indicate a high prevalence in wild species (68\%-82\% in Octodon degus; Burger et al., 2012). The finding of Bartonella DNA in this flea species is important because it is an abundant species. Although this flea has rarely been reported to feed on humans ( $\mathrm{Li} \&$ Xio, 1993), it has the potential to transmit Bartonella through the skin via contamination of infected feces, as with other Bartonellae. Nosopsyllus fasciatus presents an abundance and geographical distribution similar to L. segnis; however, the prevalence of Bartonella DNA in this species was lower, with only $8 \%$ of fleas testing positive for the bacteria, although this value is within the ranges recorded by other authors (Parola et al. 2003: 3\% [1/26]; Zurita, 2018: from 4\%-13\%). N. fasciatus and L. segnis exhibit a cosmopolitan distribution and live in temperate environments; in our study, these species were distributed in all zones, except in the hyper-arid zone, presenting with a greater abundance in the arid zone. $N$. fasciatus spends more time in the nest of its hosts than actually on them (Bitam et al., 2010) and it is fed fewer times per day (2-3 times) compared to L. segnis (35 times; Kunitskaya et al., 1965). This feature may decrease the likelihood with which these fleas acquire bacteria, as the feeding frequency and mobility of the fleas are important factors that influence pathogen transmission (Laudisoit et al., 2014). Although the prevalence of this flea was low and its transmission potential is unknown, it could be acting as a Bartonella reservoir. In addition, it is considered an important flea in public health because it occasionally infects other mammals, including humans (Pratt \& Wiseman, 1962). On the other hand, N. pardinasi was another abundant species in this study; this species was described in Argentina in parasites of Sigmodontinae rodents (Sánchez \& Lareschi, 2014). Although the prevalence of Bartonella was low in this species, this is the first report of Bartonella DNA in N. pardinasi, and the first record of this flea species in $R$. rattus in Chile. The differences in prevalence found among the flea species analyzed may be due to the specificity of Bartonella, although more studies are needed to test this hypothesis.

Although the prevalence of Bartonella in fleas detected with the gltA gene was higher than in fleas with $r$ ro $B$, this finding was not statistically significant. These genes were shown to have high discriminatory power inter-species; however, to be able to validate this species, long fragments are needed. La Scola et al. (2003) propose that newly encountered Bartonella isolates should be considered a new species if a 327-bp gltA fragment shares $<96.0 \%$ sequence similarity with those of validated species, and if an 825-bp rрoB fragment shares $<95.4 \%$ sequence 
402

403

404

405

406

407

408

409

410

411

412

413

414

415

416

417

418

419

420

421

422

423

424

425

426

427

428

429

430

431

432

433

434

435

436

437

438

439

440

441

similarity with those of validated species. Fragments shorter than those recommended by La Scola et al. were obtained ( $g l t A=142 \mathrm{bp}$ and $r p o B=95 \mathrm{bp}$ ); therefore, we could not determine with certainty if Bartonella corresponds to a new species. Although the gltA and rpoB segments used for this analysis were short, these represent a reliable taxonomic tool for distinguishing between differences among closely related organisms (Birtles \& Raoult, 1996).

Phylogenetic analysis based on the concatenated glt $A$ and $r p o B$ gene sequences identified groups close to well-known rat-associated Bartonellae: $B$. coopersplainsensis, B. mastomydis, $B$. tribocorum, B. mayotimonensis, and B. doshiae. BLAST analysis of concatenated sequences obtained from $X$. cheopis revealed 100\% similarity with Bartonella mastomydis and Bartonella sp. B28297. Both Bartonella species are found within the B. elizabethae complex (Holliday et al., 2015), but it is unknown whether they are pathogenic for humans. Nosopsyllus fasciatus from the hyper-humid zone harbored a bacterium that was $100 \%$ identical to B. tribocorum and the phylogenetic analysis also showed a close relationship with this bacterium. Although this bacterium is associated with rodents and their ectoparasites, it has recently been described as a bacterium with pathogenic potential for humans, since it was isolated in human patients from Thailand (Kosoy et al., 2010) and France, causing acute febrile illnesses and nonspecific symptoms (Vayssier-Taussat et al., 2016). Hectopsylla sp., L. segnis, and N. fasciatus presented between 96\% and 97\% similarity with Bartonella sp. 16/40 detected in the rodent Apodemus peninsulae in Russia by Mediannikov et al. (2005), although these authors indicated that this species could be new, as it is in an independent and well-isolated clade. In our study, the species was forming a well-differentiated clade, but it was related to B. coopersplainsensis (Figure 2). Bartonella DNA detected in N. chilensis and N. pardinasi showed 99\% similarity with Bartonella sp. C1phy detected in the blood of Phyllotis sp. in Peru. Similar results were found by Cicuttin et al. (2019), who detected Bartonella in Neotyphloceras crackensis in the province of Santa Cruz, Argentina, and which shared 100\% similarity with Bartonella C1phy. In the phylogenetic analysis, this Bartonella constitutes a clade with B. mayotimonensis. This bacterium has been recognized as a pathogen for humans and was isolated from the resected aortic valve tissue of a person with infective endocarditis in the United States (Lin et al., 2010). Sphynctopsylla ares showed a 95\% similarity with uncultured Bartonella sp. clone LBCE 10781 detected in Oxymycterus dasytrichus in Brazil (Rozental et al. 2017), and was found to form a monophyletic clade with $B$. doshiae. This species holds pathogenic potential in humans, since it has been detected in human patients in France who had a history of being bitten by ticks (Vayssier-Taussatet al., 2016).

It is important to know the distribution of pathogens among the different biotic communities, since it implies that certain areas pose a higher risk of infection for humans (Mills \& Childs, 1998). In our study, 10 of the 30 sampled locations ( 4 cities, 4 villages, 2 wild areas), had fleas that were positive for Bartonella DNA; it was found that villages had a higher prevalence than cities and wild areas, which coincides with the greater mean abundance and prevalence of fleas registered in villages, in addition to the differences in the dominant flea species in the different areas studied. For example, L. segnis, which had the highest prevalence of Bartonella DNA, was 
442 present in cities and villages but not in wild areas, and its mean abundance and prevalence was

443

444

445

446

447

448

449

450

451

452

453

454

455

456

457

458

459

460

461

462

463

464

465

466

467

468

469

470

471

472

473

474

475

476

477

478

479

480

greater in villages. According to our results, this species would constitute an important potential vector of Bartonella, as it is abundant in R. rattus and has a wide distribution in Chile, concentrating its greater abundance in cities and villages of the arid zone. In addition, parasitizing native rodent species were found (Beaucournu, Moreno \& González-Acuña, 2014; Burger et al., 2012). Although the prevalence of Bartonella DNA was lower in wild areas, and only parasitic flea species of native Chilean rodents were collected, this result is important because it means that $R$. rattus could disperse Bartonella species present in fleas from wild areas to rural areas. It also highlights the presence of Bartonella in wild areas, which are used as recreational spaces for people, who may then become exposed to Bartonella infection. These findings suggest that the probability of coming into contact with fleas infected with Bartonella is higher in rural areas than in cities and wild areas.

Our study shows variations in the prevalence of Bartonella in the different hydrographic zones analyzed, and the differences could be associated to both the distribution of flea species and environmental factors. A study conducted on fleas of domestic animals from Tunisia (Zouari et al., 2017) found a higher prevalence of Bartonella in fleas from humid areas, followed by semiarid, sub-humid, and arid regions; this bacterium was not found in the dry zone, contrary to what was found in our study. During our investigation, we found a higher prevalence of the bacterium in arid, semi-arid, and sub-humid zones. These differences could be explained by the differences in humidity and temperature in these areas, which determine the presence of certain flea species in some areas, affecting the dynamics of the vectors and their survival (Chinga-Alayo et al., 2004). Although in the hyper-arid zone the prevalence of fleas in rodents was low, we found only one species (X. cheopis), and noted that the prevalence of Bartonella DNA was high (6/11; $54 \%$ ). On the other hand, in our study, a significantly higher prevalence of Bartonella DNA observed in the arid zone, as compared with the other zones, could be linked with the higher prevalence of $L$. segnis and may also be responsible for the transmission of this pathogen. Bartonella prevalence did not change between seasons. Although other studies have found seasonal differences in the prevalence of Bartonella in fleas, the authors attributed these differences to changes in the population dynamics of different flea species, as well as to changes in community composition, where the dominant species changes (Telfer et al., 2007). In our study, we did not find significant changes in the composition of flea species, abundance, or prevalence among the seasons analyzed, where the most abundant and prevalent species $(L$. segnis and $N$. fasciatus) remained stable. We highlight the high richness of flea species detected in our study compared to other studies (1 to 5 species; Loftis et al., 2006; Marie et al., 2006; Li et al., 2007; Reeves et al., 2007; Tsai et al., 2010), which could be explained due to the wide geographical range considered in our study $\left(20^{\circ}\right.$ to $53^{\circ}$ lat. $)$ and also to the inclusion of wild areas, in contrast to other studies that only include rural areas or cities.

\section{Conclusions}

Peer] reviewing PDF | (2019:04:36838:1:1:NEW 21 Jun 2019) 
481 This is the first report on Bartonella DNA among a large number of flea species in rodents that 482 explored a gradient of urbanization across a wide geographic distribution in Chile. This paper 483 adds seven new species to the list of fleas already reported to carry Bartonella. Although the

484

485

486

487

488

489

490

491

492

493

494

495

496

497

498

499

500

501

502

503

504

505

506

507

508

509

510

511

512

513

514

515

516

517

518

519

520

521 prevalence of Bartonella DNA detected in this study was low, it is important to note that the villages and arid zone were the areas with the highest prevalence. In addition, the flea species that showed the highest Bartonella infection (L. segnis and X. cheopis) are fleas that have a wide distribution worldwide and are abundant in $R$. rattus. The other flea species collected in $R$. rattus corresponded to fleas that parasitize native rodents, which would indicate the degree of contact that these synanthropic rodents have with wild rodents, either directly or indirectly through the use of burrows, as they transmit parasites. This indicates that there are several species of Bartonella circulating in wild species. This finding is relevant, as parasite transmission could amplify bacterial infection among wild rodents, also increasing the probability with which infected fleas come into contact with humans in rural and wild areas. The results suggest the need to conduct further studies to verify whether these fleas might be transmitted to humans and cause disease.

\section{Acknowledgements}

We thank to Nicole Inostroza, Elaine Monalize, and Maria Ignacia Najgle for their collaboration in collecting fleas. English-language editing of this manuscript was provided by Journal Prep Services.

\section{Funding}

This work was supported by the National Fund for Scientific and Technological Development (FONDECYT) N 11150875.

\section{References}

Alsarraf M, Mohallal E, Mierzejewska E, Behnke-Borowczyk J, Welc-Falęciak R, Bednarska M, Dziewit L, Zalat S, Gilbert F, Behnke J, Bajer A. 2017. Description of Candidatus Bartonella fadhilae n. sp. and Candidatus Bartonella sanaae n. sp. (Bartonellaceae) from Dipodillus dasyurus and Sekeetamys calurus (Gerbillinae) from the Sinai Massif (Egypt). Vector-Borne and Zoonotic Diseases 17(7):483-494 DOI: 10.1089/vbz.2016.2093.

American Veterinary Medical Association. 2013. AVMA Guidelines for the Euthanasia of animals: 2013 Editions. Available at https://www.avma.org/KB/Policies/Documents/euthanasia.pdf.

Arce N, González E, Madrid V. 2017. Neurorretinitis asociada a infección por Bartonella henselae: reporte de un caso clínico y revisión de la literatura. Revista Hospital Clínico Universidad de Chile 28:12-7.

Bai Y, Kosoy MY, Lerdthusnee K, Peruski LF, Richardson JH. 2009. Prevalence and Genetic Heterogeneity of Bartonella Strains Cultured from Rodents from 17 Provinces in Thailand. The American Journal of Tropical Medicine and Hygiene 81(5):811-816 DOI:

10.4269/ajtmh.2009.09-0294. 
522 Banks PB, Hughes N. 2012. A review of the evidence for potential impacts of black rats (Rattus

523

524

525

526

527

528

529

530

531

532

533

534

535

536

537

538

539

540

541

542

543

544

545

546

547

548

549

550

551

552

553

554

555

556

557

558

559

560

561

rattus) on wildlife and humans in Australia. Wildlife Research 39(1):78 DOI: 10.1071/WR11086.

Beaucournu J, Gallardo M. 1988. Puces nouvelles d'Argentine (Insecta, Siphonaptera).

Revuesuisse de Zoologie 95(1):99-112 DOI: 10.5962/bhl.part.79641.

Beaucournu J, Murua J, Gallardo M. 1988. Description de la femelle de Ctenoparia topali Smit, 1963 et clef dichotomique du genre Ctenoparia Rothschild, 1909 (Siphonaptera, Hystrichopsyllidae). Annales de Parasitologie Humaine et Comparée 63(5):380-383 DOI: 10.1051/parasite/1988635380.

Beaucournu J, Kelt D. 1990. Contribution à la faune du Chili: puces nouvelles ou peu connues de la partie sud (Insecta, Siphonaptera). Revuesuisse de Zoologie 97(3):647-668.

Beaucournu J, Moreno L, González-Acuña D. 2011. Deux espèces nouvelles de puces

(Siphonaptera: Ctenophthalmidae \& Rhopalopsyllidae) du Chili. Parasite 18(3):241-246 DOI: 10.1051/parasite/2011183241.

Beaucournu J, Moreno L, González-Acuña D. 2014. Fleas (Insecta Siphonaptera) of Chile: A review. Zootaxa 3900(2):151-203 DOI: 10.11646/zootaxa.3900.2.1.

Billeter SA, Levy MG, Chomel BB, Breitschwerdt EB. 2008. Vector transmission of Bartonella species with emphasis on the potential for tick transmission. Medical and Veterinary Entomology 22:1-15 DOI: 10.1111/j.1365-2915.2008.00713.x.

Billeter SA, Gundi VA, Rood MP, Kosoy MY. 2011. Molecular detection and identification of Bartonella species in Xenopsylla cheopis fleas (Siphonaptera: Pulicidae) collected from Rattus norvegicus rats in Los Angeles, California. Applied and Environmental Microbiology

77(21):7850-7852 DOI: 10.1128/AEM.06012-11.

Billeter SA, Colton L, Sangmaneedet S, Suksawat F, Evans BP, Kosoy MY. 2013. Short Report: Molecular Detection and Identification of Bartonella Species in Rat Fleas from Northeastern Thailand. The American Journal of Tropical Medicine and Hygiene 89(3):462-465 DOI: 10.4269/ajtmh.12-0483.

Billeter SA, Borchert JN, Atiku LA, Mpanga JT, Gage KL, Kosoy MY. 2014. Bartonella Species in Invasive Rats and Indigenous Rodents from Uganda. Vector-Borne and Zoonotic Diseases 14(3):182-188 DOI: 10.1089/vbz.2013.1375.

Birtles RJ, Raoult D. 1996. Comparison of partial citrate synthase gene ( $g l t A)$ sequences for phylogenetic analysis of Bartonella species. International Journal of Systematic Bacteriology 46:891-897.

Bitam I, Baziz B, Rolain JM, Belkaid M, Raoult D. 2006. Zoonotic focus of Plague, Algeria. Emerging Infectious Diseases 12:1975-1977 DOI: 10.3201/eid1212.060522.

Bitam I, Dittmar K, Parola P, Whiting MF, Raoult D. 2010. Fleas and flea borne diseases. International Journal of Infectious Diseases 14:667-676 DOI: 10.1016/j.ijid.2009.11.011. Bitam I, Rolain JM, Nicolas V, Tsai YL, Parola P, Gundi VAKB, Raoult D. 2012. A multi-gene analysis of diversity of Bartonella detected in fleas from Algeria. Comparative Immunology, Microbiology and Infectious Diseases 35(1): 71-76 DOI: 10.1016/j.cimid.2011.11.002.

Peer) reviewing PDF | (2019:04:36838:1:1:NEW 21 Jun 2019) 
562 Breitschwerdt E. 2017. Bartonellosis, One Health and all creatures great and small. Veterinary

563 Dermatology 28:96-e21 DOI: 10.1111/vde.12413.

564 Buffet J-P, Kosoy M, Vayssier-Taussat M. 2013. Natural history of Bartonella-infecting rodents

565 in light of new knowledge on genomics, diversity and evolution. Future Microbiology

566 8(9):1117-1128 DOI: 10.2217/fmb.13.77.

567 Burger, Joseph R, Chesh AS, Muñoz P, Fredes F, Ebensperger LA, Hayes LD. 2012. Sociality, 568 exotic ectoparasites, and fitness in the plural breeding rodent Octodon degus. Behavioral

569 Ecology and Sociobiology 66:57-66 DOI: 10.1007/s00265-011-1252-9.

570 Chinga-Alayo E, Huarcaya E, Nasarre C, del Aguila R, Llanos-Cuentas A. 2004. The influence 571 of climate on epidemiology of bartonellosis in Ancash, Peru. Transactions of the Royal Society

572 of Tropical Medicine and Hygiene 98:116-124 DOI: 10.1016/s0035-9203(3)00017-8.

573 Chomel BB, Kasten RW, Williams C, Wey AC, Henn JB, Maggi R, Carrasco S, Mazet J,

574 Boulouis HJ, Maillard R, Breitschwerdt EB. 2009. Bartonella endocarditis: a pathology shared

575 by animal reservoirs and patients. Annals New York Academy of Science 1166:120-126 DOI:

576 10.1111/j.1749-6632.2009.04523.x.

577 Christou C, Psaroulaki A, Antoniou M, Toumazos P, Ioannou I, Mazeris A, Chochlakis D,

578 Tselentis Y. 2010. Rickettsia typhi and Rickettsia felis in Xenopsylla cheopis and Leptopsylla

579 segnis parasitizing rats in Cyprus. The American Journal of Tropical Medicine and Hygiene

580 83:1301-1304 DOI: 10.4269/ajtmh.2010.10-0118.

581 Cicuttin G, De Salvo MN, Sanchez J, Cañón C, Lareschi M. 2019. Molecular detection of

582 Bartonella in fleas (Hexapoda, Siphonaptera) collected from wild rodents (Cricetidae,

583 Sigmodontinae) from Argentina. Medical and Veterinary Entomology DOI: 10.1111/mve.12370

584 CONAMA. 2008. Biodiversidad de Chile, Patrimonio y desafíos. Comisión Nacional del Medio

585 Ambiente, Ocho Libros editors, Santiago de Chile.

586 Daly JS, Worthington MG, Brenner DJ, Moss CW, Hollis DG, Weyant RS, Steigerwalt AG,

587 Weaver RE, Daneshvar MI, O'Connor SP. 1993. Rochalimaea elizabethae sp. nov. isolated from

588 a patient with endocarditis. Journal of Clinical Microbiology 31(4):872-881.

589 Dieme C, Parola P, Guernier V, Lagadec E, Le Minter G, Balleydier E, Page`s F, Dellagi K,

590 Tortosa P, Raoult D, Socolovschi C. 2015. Rickettsia and Bartonella species in fleas from

591 Reunion Island. The American Journal of Tropical Medicine and Hygiene 92(3):617-619 DOI:

592 10.4269/ajtmh.14-0424.

593 Ellis BA, Regnery RL, Beati L, Bacellar F, Rood M, Glass GG, Marston E, Ksiazek TG, Jones

594 D, Childs JE. 1999. Rats of the genus Rattus are reservoir hosts for pathogenic Bartonella

595 species: an old world origin for a new world disease? The Journal of Infectious Diseases

596 180(1):220-224 DOI: 10.1086/314824.

597 Farhang-Azad A, Traub R, Baqar S. 1985. Transovarial transmission of murine typhus rickettsiae

598 in Xenopsylla cheopis fleas. Science 227(4686):543-545 DOI: 10.1126/science.3966162543-

599545.

Peer] reviewing PDF | (2019:04:36838:1:1:NEW 21 Jun 2019) 
600 Favacho AR, Andrade MN, de Oliveira RC, Bonvicino CR, D'Andrea PS, de Lemos ER. 2015.

601 Zoonotic Bartonella species in wild rodents in the state of Mato Grosso do Sul, Brazil. Microbes 602 and Infection 17:889-892 DOI:10.1016/j.micinf.2015.08.014.

603 Fenollar F, Sire S, Raoult D. 2005. Bartonella vinsonii subsp. arupensis as an agent of blood 604 culture-negative endocarditis in a human. Journal of Clinical Microbiology 43:945-947 DOI:

605 10.1128/JCM.43.2.945-947.2005.

606 Ferrés M, Abarca K, Godoy P, García P, Palavecino E, Méndez G, Valdés A, Ernst S, Thibaut J, 607 Koberg J, Chanqueo L, Vial P. 2005. Presencia de Bartonella henselae en gatos: cuantificación 608 del reservorio natural y riesgo de exposición humana de esta zoonosis en Chile. Revista Médica 609 de Chile 133(12):1465-1471 DOI: 10.4067/S0034-98872005001200008.

610 Friggens MM, Parmenter RR, Boyden M, Ford PL, Gage K, Keim P. 2010. Flea abundance, 611 diversity, and plague in gunnison's prairie dogs (Cynomys gunnisoni) and their burrows in 612 montane grasslands in northern New Mexico. Journal of Wildlife Diseases 46(2):356-367 DOI: 613 10.7589/0090-3558-46.2.356.

614 Gárate I, Jiménez P, Flores K, Espinoza B. 2011. Registro de Xenopsylla cheopis como 615 hospedero intermediario natural de Hymenolepis diminuta en Lima, Perú. Revista Peruana de 616 Biología 18(2):249-252.

617 Gonçalves LR, Favacho ARM, Roque ALR, Mendes NS, Junior OLF, Benevenute JL, Herrera 618 EM, D'Andrea PS, de Lemos ERS, Machado RZ, André MR. 2016. Association of Bartonella 619 species with wild and synanthropic rodents in different brazilian biomes. Applied and 620 Environmental Microbiology 82(24):7154-7164 DOI: 10.1128/AEM.02447-16.

621 Guernier V, Lagadec E, LeMinter G, Licciardi S, Balleydier E, Pagès F, Laudisoit A, Dellagi K, 622 Tortosa P. 2014. Fleas of small mammals on Reunion Island: diversity, distribution and

623 epidemiological consequences. PLOS Neglected Tropical Diseases 8(9):e3264 DOI:

624 10.1371/journal.pntd.0003129.

625 Harris DB. 2009. Review of negative impacts of introduced rodents on small mammals on

626 islands. Biological Invasions 11: 1611-30 DOI: 10.1007/s10530-008-9393-0.

627 Hastriter MW, Whiting MF. 2003. Siphonaptera (fleas). In: Resh VH, Carde R, eds.

628 Encyclopedia of Insects. Elsevier Science Orlando, 1039-1045.

629 Herbreteau V, Jittapalapong S, Rerkamnuaychoke W, Chaval Y, Cosson J-F, Morand S.

630 (Editors). 2011. Protocols for field and laboratory rodent studies. Retrieved from CERoPath

631 project. Available at http://www.ceropath.org/FichiersComplementaires/Herbreteau_

632 Rodents_protocols_2011.pdf.

633 Hopkins G, Rothschild M. 1956. An illustrated catalogue of the Rothschild collection of fleas

634 (Siphonaptera) in the British Museum (Natural History). Vol II, Coptopsyllidae, Vermipsyllidea, 635 Stephanocircidae, Ischnopsyllidae, Hypsophthalmidae and Xiphiopsyllidae. British Museum 636 (Natural History), London.

637 Hopkins G, Rothschild M. 1962. An illustrated catalogue of the Rothschild collection of fleas

638 (Siphonaptera) in the British Museum (Natural History). Vol III, Hystrichopsyllidae

Peer] reviewing PDF | (2019:04:36838:1:1:NEW 21 Jun 2019) 
639 (Acedestiinae, Anomiosyllinae, Hystrichopsyllinae, Neopsyllinae, Rhadinopsyllinae and 640 Stenoponiinae). British Museum (Natural History), London.

641 Hopkins G, Rothschild M. 1966. An illustrated catalogue of the Rothschild collection of fleas

642 (Siphonaptera) in the British Museum (Natural History). Vol IV, Hystrichopsyllidae

643 (Ctenophthalminae, Dinopsyllinae, Doratopsyllinae and Listropsyllinae). British Museum

644 (Natural History), London.

645 Hornok S, Földvári G, Rigó K, Meli ML, Gönczi E, Répási A, Farkas R, Papp I, Kontschán J, 646 Hofmann-Lehmann R. 2015. Synanthropic rodents and their ectoparasites as carriers of a novel 647 haemoplasma and vector-borne, zoonotic pathogens indoors. Parasites Vectors 8(1) DOI:

648 10.1186/s13071-014-0630-3.

649 Hsieh J-W, Tung K-C, Chen W-C,Lin J-W, Chien L-J, Hsu Y-M, Wang H-C, Chomel BB, 650 Chang C-C. 2010. Epidemiology of Bartonella infection in rodents and shrews in Taiwan.

651 Zoonoses and Public Health 57(6):439-446 DOI: 10.1111/j.1863-2378.2009.01234.x.

652 INE. 2005. Chile: Ciudades, Pueblos, Aldeas y Caserios. Instituto Nacional de Estadísticas, 653 Chile.

654 Iriarte A. 2007. Mamiferos de Chile. Lynx edicions, Santiago, Chile.

655 Jiyipong S, Jittapalapong S, Morand J-M. 2014. Bartonella species in small mammals and their 656 potential vectors in Asia. Asian Pacific Journal of Tropical Biomedicine 4(10):757-767 DOI:

657 10.12980/APJTB.4.2014C742.

658 Klangthong K, Promsthaporn S, Leepitakrat S, Schuster A L, McCardle PW, Kosoy M, 659 Takhampunya R. 2015. The distribution and diversity of Bartonella species in rodents and their 660 ectoparasites across Thailand. PLoS One 10(10) DOI:

661 e0140856.doi:10.1371/journal.pone.0140856.

662 Kosoy M, Murray M, Gilmore RD, Bai Y, Gage KL. 2003. Bartonella strains from ground 663 squirrels are identical to Bartonella washoensis isolated from a human patient. Journal of 664 Clinical Microbiology 41(2):645-50 DOI: 10.1128/JCM.41.2.645-650.2003.

665 Kosoy M, Morway C, Sheff KW, Bai Y, Colborn J, Chalcraft L, Dowell SF, Peruski LF, 666 Maloney SA, Baggett H, Sutthirattana S, Sidhirat A, Maruyama S, Kabeya H, Chomel BB, 667 Kasten R, Popov V, Robinson J, Kruglov A, Petersen LR. 2008. Bartonella tamiae sp. nov., a 668 newly recognized pathogen isolated from three human patients from Thailand. Journal of 669 Clinical Microbiology 46(2):772-5 DOI: 10.1128/JCM.02120-07.

670 Kosoy M, Bai Y, Sheff K, Morway C, Baggett H, Maloney SA, Boonmar S, Bhengsri S, Dowell 671 SF, Sitdhirasdr A, Lerdthusnee K, Richardson J, Peruski LF. 2010. Identification of Bartonella 672 infections in febrile human patients from Thailand and their potential animal reservoirs. The 673 American Journal of Tropical Medicine and Hygiene 82(6):1140-1145 DOI:

674 10.4269/ajtmh.2010.09-0778.

675 Krystufek B, Palomo L, Hutterer R, Mitsain G, Yigit N. 2016. Rattus rattus (errata version 676 published in 2017). The IUCN Red List of Threatened Species 2016: e.T19360A115148682 677 DOI: 10.2305/IUCN.UK.2016-3.RLTS.T19360A15137085.en. Available at 678 https://www.iucnredlist.org/species/19360/115148682 (accessed 13 March 2018). 
679 Kumar S, Stecher G, Tamura K. 2016. MEGA7: Molecular Evolutionary Genetics Analysis

680 Version 7.0 for Bigger Datasets. Molecular Biology and Evolution 33(7):1870-1874 DOI:

681 10.1093/molbev/msw054.

682 Kunitskaya NT, Gauzshtein DM, Kunitsky VN, Rodionov IA, Filimonov VI. 1965. Feeding

683 activity of fleas parasitic on the great gerbil in experiments. In: Proceedings of the 4th Scientific

684 Conference on Natural Focality and Prophylaxis of Plague, ed. Anonymous. Alma-Ata, USSR:

685 Kainar, pp. 135-137.

686 La Scola B, Zeaiter Z, Khamis A, Raoult D. 2003. Gene-sequence-based criteria for species

687 definition in bacteriology: the Bartonella paradigm. Trends in Microbiology 11:318-321 DOI:

688 10.1016/S0966-842X(03)00143-4.

689 Laudisoit A, Falay D, Amundala D, Akaibe D, Goüy de Bellocq J, Van Houtte N, Breno M, 690 Verheyen E, Wilschut L, Parola P, Raoult D, Socolovschi C. 2014. High prevalence of Rickettsia

691 typhi and Bartonella species in rats and fleas, Kisangani, Democratic Republic of the Congo. The 692 American Journal of Tropical Medicine and Hygiene 90(3):463-468 DOI: 10.4269/ajtmh.13-

6930216.

694 Leulmi H, Socolovschi C, Laudisoit A, Houemenou G, Davoust B, Bitam I, Raoult D, Parola P.

695 2014. Detection of Rickettsia felis, Rickettsia typhi, Bartonella species and Yersinia pestis in

696 Fleas (Siphonaptera) from Africa. PLoS Neglected Tropical Diseases 8(10):e3152 DOI:

697 10.1371/journal.pntd.0003152.

698 Li DM, Liu QY, Yu DZ, Zhang JZ, Gong ZD, Song XP. 2007. Phylogenetic analysis of 699 bartonella detected in Rodent fleas in Yunnan, China. Journal of Wildlife Diseases 43(4):609-

700 617 DOI: 10.7589/0090-3558-43.4.609.

701 Li Z-1, Xio B-1. 1993. Observations on the breeding and biological characteristics of Leptopsylla 702 segnis. Endemic Disease Bulletin 8:26-28.

703 Lin EY, Tsigrelis C, Baddour LM, Lepidi H, Rolain JM, Patel R, D. Roult. 2010. Candidatus

704 Bartonella mayotimonensis and endocarditis. Emerging Infectious Diseases 16:500-503 DOI:

705 10.3201/eid1603.081673.

706 Linardi PM, Moreira de Avelar D. 2014. Neosomes of tungid fleas on wild and domestic

707 animals. Parasitology Research 113:3517-3533 DOI: 10.1007/s00436-014-4081-8.

708 Lipatova I, Paulauskas A, Puraite I, Radzijevskaja J, Balciauskas L, Gedminas V. 2015.

709 Bartonella infection in small mammals and their ectoparasites in Lithuania. Microbes and

710 Infection 17:884-888 DOI: 10.1016/j.micinf.2015.08.013.

711 Lobos G, Ferres M, Palma RE. 2005. Presencia de los géneros invasores Mus y Rattus en áreas

712 naturales de Chile: un riesgo ambiental y epidemiológico. Revista Chilena de Historia Natural

713 78(1):113-124 DOI: 10.4067/S0716-078X2005000100008.

714 Loftis AD, Reeves WK, Szumlas DE, Abbassy MM, Helmy IM, Moriarity JR, Dasch GA. 2006.

715 Surveillance of Egyptian fleas for agents of public health significance: Anaplasma, Bartonella,

716 Coxiella, Ehrlichia, Rickettsia, and Yersinia pestis. The American Journal of Tropical Medicine 717 and Hygiene 75(1):41-48 DOI: 10.4269/ajtmh.2006.75.41. 
718 Marie JL, Fournier PE, Rolain JM, Briolant S, Davoust B, Raoult D. 2006. Molecular detection 719 of Bartonella quintana, B. elizabethae, B. koehlerae, B. doshiae, B. taylorii, and Rickettsia felis 720 in rodent fleas collected in Kabul, Afghanistan. The American Journal of Tropical Medicine and 721 Hygiene 74:436-439 DOI: 10.4269/ajtmh.2006.74.436.

722 McKee CD, Osikowicz LM, Schwedhelm TR, Maes SE, Enscore RE, Gage KL, Kosoy MY.

723 2018. Acquisition of Bartonella elizabethae by experimentally exposed oriental rat fleas

724 (Xenopsylla cheopis; Siphonaptera, Pulicidae) and excretion of Bartonella DNA in flea feces.

725 Journal of Medical Entomology 55(5):1292-1298 DOI: 10.1093/jme/tjy085.

726 Mediannikov O, Ivanov L, Zdanovskaya N, Vysochina N, Fournier PE, Tarasevich I, Raoult D.

727 2005. Molecular screening of Bartonella species in rodents from the Russian Far East. Annals of

728 the New York Academy of Sciences 1063(1):308-311 DOI: 10.1196/annals.1355.049.

729 Mills JN, Yates TL, Childs JE, Parmenter RR, Ksiazek TG, Rollin PE, Peters CJ. 1995.

730 Guidelines for Working with Rodents Potentially Infected with Hantavirus. Journal of

731 Mammalogy 76(3):716-722 DOI: 10.2307/1382742.

732 Mills JN, Childs JE. 1998. Ecologic studies of rodent reservoirs: their relevance for human

733 health. Emerging Infectious Diseases 4: 529-537 DOI: 10.3201/eid0404.980403.

734 Müller A, Walker R, Bittencourt P, Machado RZ, Benevenute JL, DO Amaral RB, Gonçalves

735 LR, André MR. 2017. Prevalence, hematological findings and genetic diversity of Bartonella

736 spp. in domestic cats from Valdivia, Southern Chile. Parasitology 144(6):773-782 DOI:

737 10.1017/S003118201600247X.

738 Pangjai D, Maruyama S, Boonmar S, Kabeya H, Sato S, Nimsuphan B, Petkanchanapong W,

739 Wootta W, Wangroongsarb P, Boonyareth M, Preedakoon P, Saisongkorh W, Sawanpanyalert P.

740 2014. Prevalence of zoonotic Bartonella species among rodents and shrews in Thailand.

741 Comparative Immunology Microbiology and Infectious Diseases 37(2):109-114 DOI:

742 10.1016/j.cimid.2013.12.001.

743 Parola P, Sanogo OY, Lerdthusnee K, Zeaiter Z, Chauvancy G, Gonzalez JP, Miller RS, Telford

744 SR 3rd, Wongsrichanalai C, Raoult D. 2003. Identification of Rickettsia spp. and Bartonella spp.

745 in from the Thai-Myanmar border. Annals of the New York Academy of Sciences 990(1):173-181

746 DOI: 10.1111/j.1749-6632.2003.tb07359.x.

747 Pérez-Martínez L, Venzal JM, González-Acuña D, Portillo A, Blanco JR, Oteo JA. 2009.

748 Bartonella rochalimae and other Bartonella spp. in fleas, Chile. Emerging Infectious Diseases

749 15:1150-1152 DOI: 10.3201/eid1507.081570

750 Peterson AC, Ghersi BM, Alda F, Firth C, Frye M, Bai Y, Osikowicz L, Riegel C, Lipkin W,

751 Kosoy M, Blum M. 2017. Rodent-Borne Bartonella infection varies according to host species

752 within and among cities. EcoHealth 14:771 DOI: 10.1007/s10393-017-1291-4.

753 Pratt HD, Wiseman JS. 1962. Fleas of public health importance and their control. Training guide

754 - Insect control series. U. S. Department of Health, Education, and Welfare Public Health

755 Service Communicable Disease Center Atlanta, Georgia. PHS Publication No. 772. 
756 Reeves WK, Rogers TE, Durden LA, Dasch GA. 2007. Association of Bartonella with the fleas

757 (Siphonaptera) of rodents and bats using molecular techniques. Journal of Vector Ecology

758 32(1):118-122 DOI: 10.3376/1081-1710.

759 Ronquist F, Teslenko M, Van Der Mark P, Ayres DL, Darling A, Hohna S, Larget B, Liu L,

760 Suchard M, Huelsenbeck JP. 2012. MrBayes 3.2: Efficient Bayesian phylogenetic inference and

761 model choice across a large model space. Systematic Biology 61(3):539-542 DOI:

762 10.1093/sysbio/sys029.

763 Rozental T, Ferreira MS, Gutierres A, Mares-Guia MA, Teixeira BR, Goncalves J, Bonvicino

764 CR, D'Andrea PS, de Lemos ER. 2017. Zoonotic pathogens in Atlantic Forest wild rodents in

765 Brazil: Bartonella and Coxiella infections. Acta Tropica 168:64-73 DOI:

766 10.1016/j.actatropica.2017.01.003.

767 Rozsa L, Reiczigel J, Majoros G. 2000. Quantifying parasites in samples of hosts. Journal of

768 Parasitology 86:228-232 DOI: 10.1645/0022-3395.

769 Sánchez J, Amor V, Bazán-León E, Vásquez R, Lareschi M. 2012. Redescription of

770 Neotyphloceras chilensis Jordan, new status (Siphonaptera: Ctenophthalmidae:

771 Neotyphloceratini). Zootaxa 3259:51-57 DOI: 10.5281/zenodo.280702.

772 Sánchez J, Lareschi M. 2014. Two new species of Neotyphloceras (Siphonaptera:

773 Ctenophthalmidae) from Argentinean Patagonia. Zootaxa 3784(2):159-170 DOI:

774 10.11646/zootaxa.3784.2.5.

775 Sandoval C, Pinochet C, Peña A, Rabello M, Prado A, Viviani T. 2014. Síndrome febril

776 prolongado: un desafío para el infectólogo pediatra. Revista Chilena de Infectología

777 31(1):87-91. DOI: 10.4067/S0716-10182014000100013.

778 Schramm BA. 1987. A taxonomic revision of the genus Plocopsylla Jordan, 1931 (Siphonaptera:

779 Stephanocircidae). PhD Retrospective Theses and Dissertations. 8591. Iowa State University,

780 Ames, Iowa.

781 Serratrice J, Rolain JM, Granel B, Ene N, Conrath J, Avierinos JF, Disdier P, Raoult D, Weiller

782 PJ. 2003. Bilateral retinal artery branch occlusions revealing Bartonella grahamii infection. La

783 Revue de Medecine Interne 24:629-630 DOI: 10.1016/S0248-8663(03)00224-8.

784 Smit FGAM. 1987. An illustrated catalogue of the Rothschild Collection of fleas (Siphonaptera)

785 in the British Museum (Natural History) 7: Malacopsylloidea (Malacopsyllidae and

786 Rhopalopsyllidae). Oxford University, UK., 380 pp.

787 Telfer S, Begon M, Bennett M, Bown KJ, Burthe S, Lambin X, Telford G, Birtle R. 2007.

788 Contrasting dynamics of Bartonella spp.in cyclic field vole populations: the impact of vector and 789 host dynamics. Parasitology 134(Pt3):413-425 DOI: 10.1017/S0031182006001624.

790 Towns DR, Atkinson IAE, Daugherty CH. 2006. Have the harmful effects of introduced rats on

791 islands been exaggerated? Biological Invasions 8:863-891 DOI 10.1007/s10530-005-0421-z

792 Troncoso I, Fischer C, Arteaga F, Espinoza C, Azócar T, Abarca K. 2016. Seroprevalencia de

793 Bartonella henselae en personas con riesgo ocupacional. Revista Chilena de Infectología 33(3):

794 355-357 DOI: 10.4067/S0716-10182016000300019. 
795 Tsai YL, Chuang ST, Chang CC, Kass PH, Chomel BB. 2010. Bartonella species in small 796 mammals and their ectoparasites in Taiwan. The American Journal of Tropical Medicine and 797 Hygiene 83(4): 917-923 DOI: 10.4269/ajtmh.2010.10-0083.

798 Uribe P, Balcells ME, Giesen L, Cárdenas C, García P, González S. 2012. Angiomatosis bacilar 799 por Bartonella quintana como primera manifestación de infección por VIH: Report of one case. 800 Revista Médica de Chile 140(7):910-914 DOI: 10.4067/S0034-98872012000700013.

801 Vayssier-Taussat M, Moutailler S, Féménia F, Raymond P, Croce O, La Scola B, Fournier PE, 802 Raoult D. 2016. Identification of novel zoonotic activity of Bartonella spp., France. Emerging 803 Infectious Diseases 22(3): 457-462 DOI: 10.3201/eid2203.150269.

804 Winoto IL, Goethert H, Ibrahim IN, Yuniherlina I, Stoops C, Susanti I, Kania W, Maguire JD, 805 Bangs MJ, Telford SR, Wongsrichanalai C. 2005. Bartonella species in rodents and shrews in 806 the greater Jakarta area. The Southeast Asian Journal of Tropical Medicine and Public Health 807 36(6):1523-1529.

808 Xia X, Xie Z, Salemi M, Chen L, Wang Y. 2003. An index of substitution saturation and its 809 application. Molecular Phylogenetics and Evolution 26:1-7 DOI: 10.1016/S1055810 7903(02)00326-3.

811 Xia X, Lemey P. 2009. Assessing substitution saturation with DAMBE. In: Lemey P,

812 Vandamme AM, eds. The Phylogenetic Handbook: A Practical Approach to DNA and Protein

813 Phylogeny. 2nd edition Cambridge University Press, 615-630.

814 Xia X. 2017. DAMBE6: New Tools for Microbial Genomics, Phylogenetics, and Molecular

815 Evolution. Journal of Heredity 108(4):431-437 DOI: 10.1093/jhered/esx033.

816 Ying B, Kosoy MY, Maupin GO, Tsuchiya KR, Gage KL. 2002. Genetic and ecologic

817 characteristics of Bartonella communities in rodents in southern China. The American Journal of

818 Tropical Medicine and Hygiene 66(5):622-627 DOI: 10.4269/ajtmh.2002.66.622.

819 Ying, B, Kosoy MY, Diaz MH, Winchell J, Baggett H, Maloney SA, Boonmar S, Bhengsri S, 820 Sawatwong P, Peruski LF. 2012. Bartonella vinsonii subsp. arupensis in humans, Thailand.

821 Emerging Infectious Diseases 18(6):989-991 DOI: 10.3201/eid1806.111750.

822 Zaror L, Ernst S, Navarrete M, Ballesteros A, Boroschek D, Ferres M, Thibaut J. 2002.

823 Detección serológica de Bartonella henselae en gatos en la ciudad de Valdivia, Chile. Archivos

824 de Medicina Veterinaria 1: 103-110 DOI: 10.4067/S0301-732X2002000100011.

825 Zepeda J, Morales J, Letelier H, Delpiano L. 2016. Osteomielitis vertebral por Bartonella

826 henselae: a propósito de un caso. Revista Chilena de Pediatría 87(1):53-58 DOI:

827 10.1016/j.rchipe.2015.08.004.

828 Zouari S, Khrouf F, M'ghirbi Y, Bouattour A. 2017. First molecular detection and

829 characterization of zoonotic Bartonella species in fleas infesting domestic animals in Tunisia.

830 Parasites \& Vectors 10:436 DOI 10.1186/s13071-017-2372-5.

831 Zurita A. 2018. Taxonomía, filogenia y papel vectorial de especies del orden Siphonaptera.

832 Doctoral Thesis, Universidad de Sevilla. 
Figure 1

Map of Chile indicating the location of the study sites.

Each data point indicates sample locality. Gray circle: locality featuring rats without fleas; Circle with a cross: locality featuring rats with fleas; Black triangle: locality featuring fleas that tested positive for Bartonella DNA; White circle: locality without rats. 


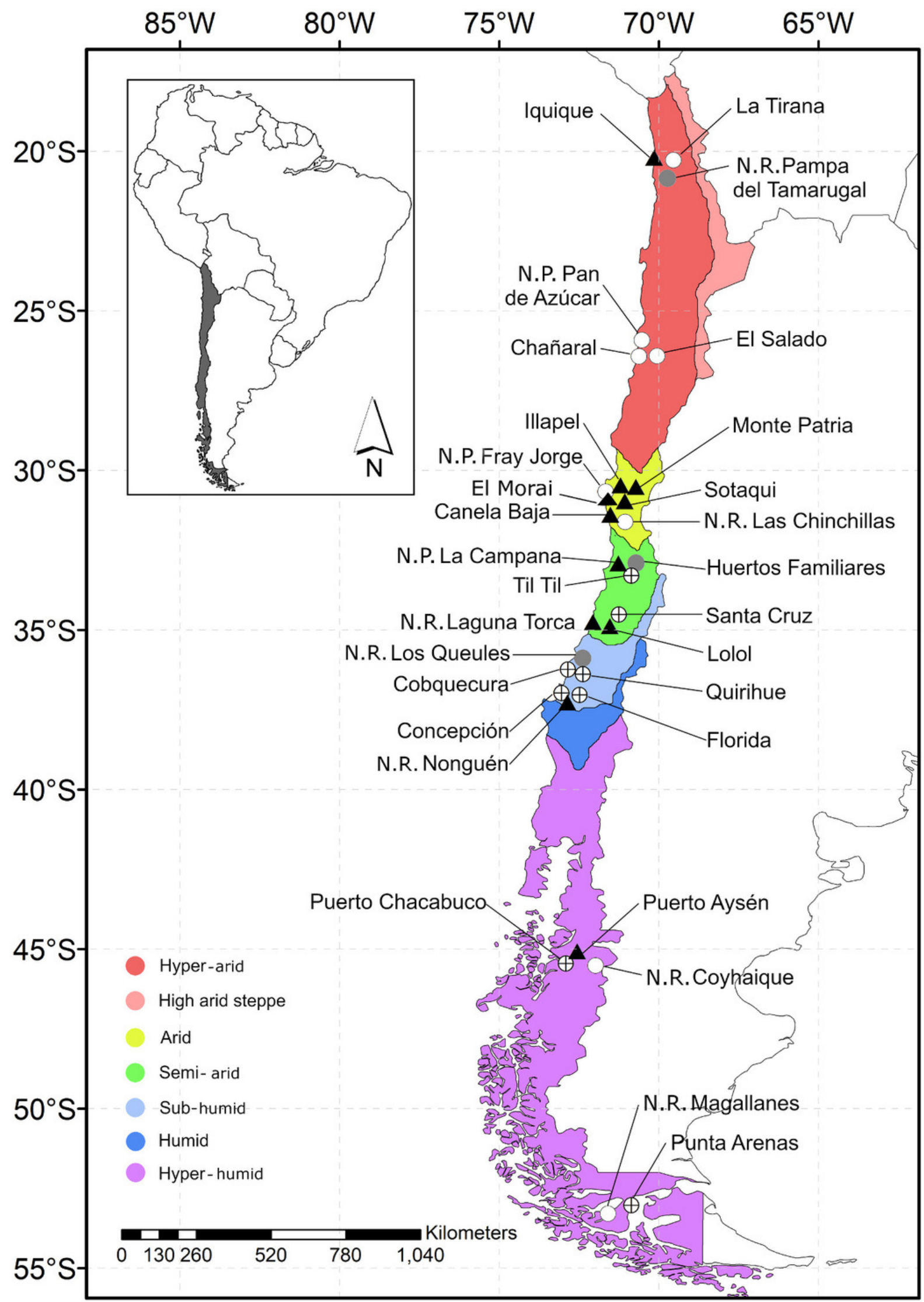




\section{Figure 2}

Phylogenetic tree of Bartonella, as based on concatenated gltA and rpoB genes using a GTR substitution model.

The phylogenetic tree was constructed using a Bayesian method. Brucella abortus was included as an outgroup. Bootstrap values were calculated with 10,000,000 replicates. The corresponding accession number for each genotype is indicated below each species of Bartonella. The flea species from which Bartonella DNA was detected is indicated, and the locality and the location from where it was collected is noted in parentheses. 


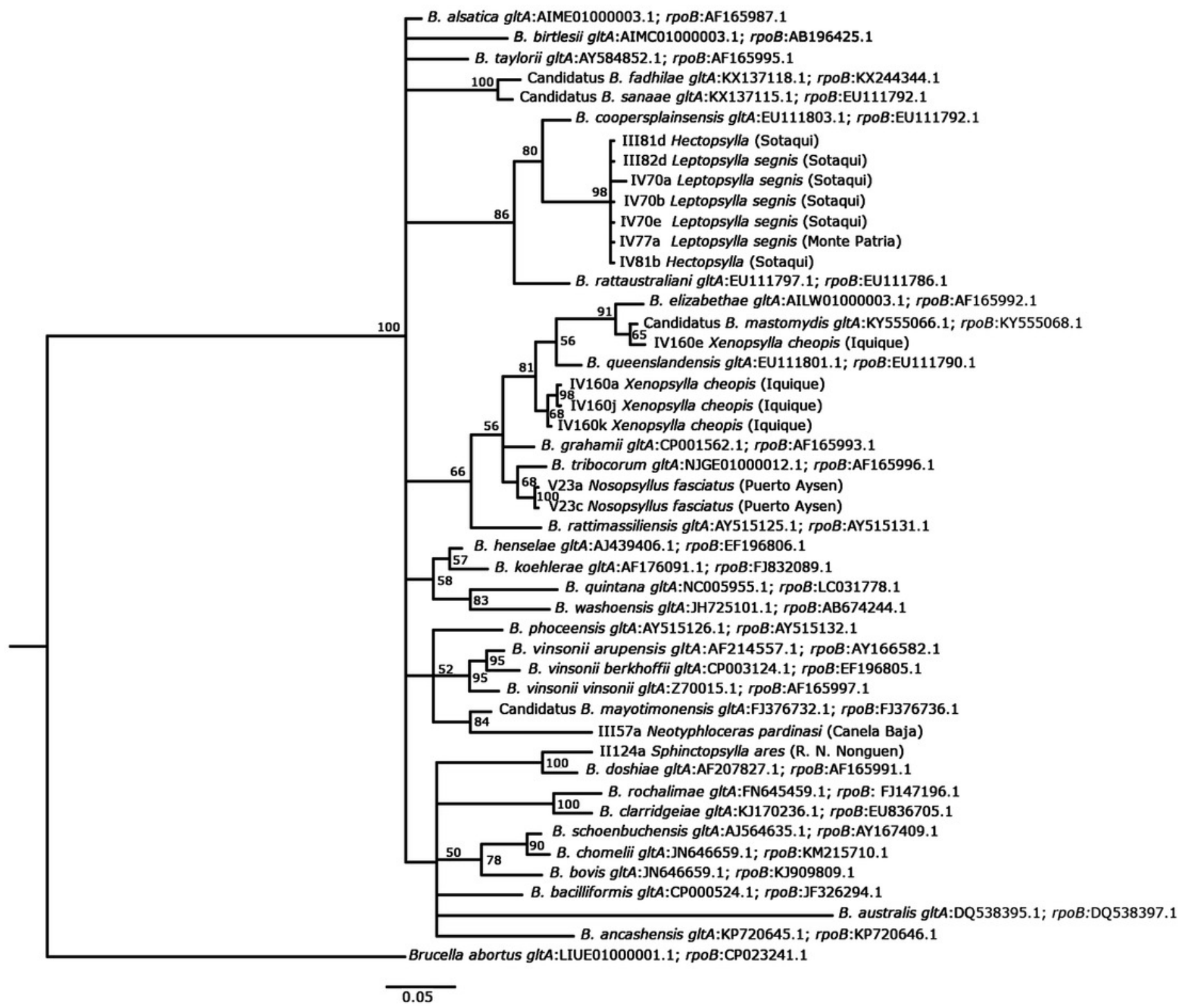




\section{Table 1 (on next page)}

Primer sequences used for PCR amplifications. F: forward; R: reverse.

F: forward; R: reverse. 
1

\begin{tabular}{lll}
\hline Name & Primer & Product lenght (bp) \\
\hline BaGlta_F & TCTACGGTACGTCTTGCTGGATCA & 201 \\
BaGlta_R & GCCCATAAGGCGGAAAGGATCATT & 201 \\
BaRpoB_F & CGCGCGATCATGTTGATTTGATGG & 159 \\
BaRpoB_R & ATGGTGCTTCAGCACGTACAAGAG & 159 \\
\hline
\end{tabular}




\section{Table 2 (on next page)}

Detection of Bartonella DNA from fleas collected on Rattus rattus from different seasons and locality types. 


\begin{tabular}{|c|c|c|c|c|c|c|c|c|}
\hline \multirow[t]{2}{*}{ Family } & \multirow[t]{2}{*}{ Specie of flea } & \multicolumn{2}{|c|}{$\begin{array}{c}\text { Total of fleas } \\
\text { analyzed by seasons }\end{array}$} & \multicolumn{3}{|c|}{$\begin{array}{l}\text { Total of fleas analyzed by type } \\
\text { of locality }\end{array}$} & \multicolumn{2}{|c|}{$\begin{array}{l}\mathrm{N}^{\circ} \text { of fleas positive } \\
\text { for gene fragment }\end{array}$} \\
\hline & & Summer & Winter & City & Village & Reserve & gltA & rpoB \\
\hline Pulicidae & Xenopsylla cheopis & 0 & 11 & 11 & 0 & 0 & $7(63.6)$ & $5(45.5)$ \\
\hline Leptopsyllidae & Leptopsylla segnis & 22 & 33 & 19 & 36 & 0 & $19(34.5)$ & $15(27.3)$ \\
\hline Ceratophyllidae & Nosopsyllus fasciatus & 19 & 26 & 33 & 12 & 0 & $4(8.9)$ & $4(8.9)$ \\
\hline Hectopsyllidae & Hectopsylla sp. & 3 & 0 & 0 & 3 & 0 & $3(100)$ & $2(66.7)$ \\
\hline \multirow[t]{5}{*}{ Hystrichopsyllidae } & Ctenoparia inopinata & 1 & 0 & 1 & 0 & 0 & 0 & 0 \\
\hline & Ctenoparia jordani & 0 & 1 & 0 & 0 & 1 & 0 & 0 \\
\hline & Neotyphloceras sp. & 4 & 0 & 1 & 3 & 0 & 0 & $1(25.0)$ \\
\hline & Neotyphloceras chilensis & 2 & 0 & 0 & 2 & 0 & $1(50.0)$ & $1(50.0)$ \\
\hline & Neotyphloceras pardinasi & 14 & 9 & 9 & 6 & 8 & $1(4.3)$ & $3(13.0)$ \\
\hline \multirow[t]{3}{*}{ Rhopalopsyllidae } & Delostichus coxalis & 6 & 0 & 0 & 0 & 6 & 0 & $1(16.7)$ \\
\hline & Delostichus smiti & 0 & 1 & 1 & 0 & 0 & 0 & 0 \\
\hline & Tetrapsyllus rhombus & 1 & 2 & 0 & 1 & 2 & $1(33.3)$ & 0 \\
\hline \multirow[t]{3}{*}{ Stephanocircidae } & Plocopsylla sp. & 0 & 2 & 1 & 0 & 1 & 0 & 0 \\
\hline & Plocopsylla wolffsohni & 0 & 1 & 0 & 1 & 0 & 0 & 0 \\
\hline & Sphinctopsylla ares & 3 & 13 & 5 & 2 & 9 & $1(6.2)$ & $2(12.5)$ \\
\hline Total & & 75 & 99 & 81 & 66 & 27 & $37(21.2)$ & 34 (19.5) \\
\hline
\end{tabular}




\section{Table 3(on next page)}

Prevalence, mean abundance, and mean intensity of fleas, as well as the prevalence of Bartonella DNA from black rats captured from five hydrographic zones and 21 localities in Chile. 


\begin{tabular}{|c|c|c|c|c|c|c|c|c|}
\hline $\begin{array}{l}\text { Hydrographic } \\
\text { zone }\end{array}$ & Locality & $\begin{array}{c}\text { Number } \\
\text { rodent }\end{array}$ & $\begin{array}{l}\% \text { Prevalence of } \\
\text { fleas }(95 \% \mathrm{CI})\end{array}$ & $\begin{array}{l}\text { Abundance mean } \\
\text { of fleas }(95 \% \mathrm{CI})\end{array}$ & $\begin{array}{c}\text { Intensity mean } \\
\text { of fleas ( } 95 \% \\
\text { CI) }\end{array}$ & $\begin{array}{l}\text { Number of } \\
\text { fleas } \\
\text { analyzed }\end{array}$ & $\begin{array}{l}\text { Number of } \\
\text { fleas } \\
\text { positive to } \\
\text { glt } A(\%)\end{array}$ & $\begin{array}{c}\text { Number of } \\
\text { fleas positive } \\
\text { rpoB }(\%)\end{array}$ \\
\hline \multirow[t]{2}{*}{ Hyper-arid } & Iquique $^{\mathrm{C}}$ & 2 & $50.0(0.01-0.99)$ & $5.5(0.00-5.50)$ & $11.0^{*}$ & 11 & $7(63.6)$ & $5(71.4)$ \\
\hline & N.P Pampa del Tamarugal ${ }^{\mathrm{W}}$ & 10 & 0.0 & 0.0 & - & 0 & $0(0.0)$ & $0(0.0)$ \\
\hline \multirow[t]{5}{*}{ Arid } & Illapel $^{\mathrm{C}}$ & 17 & $76.5(0.50-0.93)$ & $3.2(1.53-4.00)$ & $4.2(2.15-5.00)$ & 33 & $2(6.1)$ & $1(3.0)$ \\
\hline & Monte Patria ${ }^{\mathrm{C}}$ & 14 & $42.9(0.13-0.65)$ & $0.9(0.14-1.14)$ & $2.0(1.00-2.20)$ & 7 & $1(14.3)$ & $1(14.3)$ \\
\hline & El Morai ${ }^{\mathrm{V}}$ & 8 & $25.0(0.03-0.65)$ & $0.5(0.00-1.50)$ & $2.0(1.00-2.00)$ & 4 & $0(0.0)$ & $0(0.0)$ \\
\hline & Canela Baja $^{\mathrm{V}}$ & 6 & $50.0(0.12-0.88)$ & $1.8(0.17-4.67)$ & $3.7(1.00-5.67)$ & 8 & $2(25.0)$ & $7(87.5)$ \\
\hline & Sotaquí ${ }^{V}$ & 14 & $85.7(0.57-0.98)$ & $4.8(2.57-7.21)$ & $5.6(3.25-8.17)$ & 40 & $21(52.5)$ & $13(32.5)$ \\
\hline \multirow[t]{6}{*}{ Semi-arid } & Til Til ${ }^{\mathrm{C}}$ & 3 & $33.3(0.01-0.91)$ & $0.3(0.00-0.67)$ & $1.0^{*}$ & 1 & $0(0.0)$ & $0(0.0)$ \\
\hline & Santa Cruz ${ }^{\mathrm{C}}$ & 5 & $20.0(0.01-0.72)$ & $0.2(0.00-0.40)$ & $1.0^{*}$ & 0 & $0(0.0)$ & $0(0.0)$ \\
\hline & Huertos Familiares $\mathrm{V}$ & 2 & 0.0 & 0.0 & - & 0 & $0(0.0)$ & $0(0.0)$ \\
\hline & Lolol $^{\mathrm{V}}$ & 1 & $100.0(0.25-1.00)$ & $4.0^{*}$ & $4.0^{*}$ & 4 & $0(0.0)$ & $1(25.0)$ \\
\hline & N.P. La Campana ${ }^{\mathrm{W}}$ & 22 & $22.7(0.08-0.45)$ & $0.6(0.18-1.14)$ & $2.6^{*}$ & 13 & $1(7.7)$ & $1(7.7)$ \\
\hline & N.R. Laguna Torca ${ }^{W}$ & 2 & $50.0(0.01-0.99)$ & $2.5(0.00-2.50)$ & $5.0^{*}$ & 5 & $0(0.0)$ & $2(40.0)$ \\
\hline \multirow[t]{5}{*}{ Sub-humid } & Quirihue $^{\mathrm{C}}$ & 77 & $13.0(0.06-0.22)$ & $0.2(0.09-0.40)$ & $1.6(1.10-2.40)$ & 15 & $0(0.0)$ & $0(0.0)$ \\
\hline & Concepción ${ }^{\mathrm{C}}$ & 22 & $22.7(0.08-0.45)$ & $0.4(0.09-0.77)$ & $1.6(1.00-2.20)$ & 8 & $0(0.0)$ & $0(0.0)$ \\
\hline & Cobquecura $^{\mathrm{V}}$ & 1 & $100.0(0.02-1.00)$ & $2.0^{*}$ & $2.0^{*}$ & 2 & $0(0.0)$ & $0(0.0)$ \\
\hline & Florida $^{\mathrm{V}}$ & 18 & $22.2(0.64-0.48)$ & $0.3(0.06-0.78)$ & $1.5(1.00-2.00)$ & 6 & $0(0.0)$ & $0(0.0)$ \\
\hline & N.R. Nonguén ${ }^{\mathrm{W}}$ & 25 & $48.0(0.28-0.69)$ & $0.8(0.44-1.36)$ & $1.7(1.17-2.58)$ & 9 & $1(11.1)$ & $1(11.1)$ \\
\hline \multirow[t]{3}{*}{ Hiper-humid } & Puerto Aysén ${ }^{C}$ & 4 & $25.0(0.01-0.80)$ & $1.5(0.0-3.0)$ & $6.0^{*}$ & 5 & $2(40.0)$ & $2(40.0)$ \\
\hline & Punta Arenas ${ }^{\mathrm{C}}$ & 5 & $20.0(0.01-0.72)$ & $0.2(0.0-0.4)$ & $1.0^{*}$ & 1 & $0(0.0)$ & $0(0.0)$ \\
\hline & Puerto ChacabucoV & 3 & $33.3(0.01-0.91)$ & $0.7(0.0-1.33)$ & $2.0^{*}$ & 2 & $0(0.0)$ & $0(0.0)$ \\
\hline
\end{tabular}

C: City; V: Village; W: Wild area; N.P: National Park; N.R. National Reserve 


\section{Table 4 (on next page)}

Prevalence of the Bartonella species in fleas collected from different localities and seasons in Chile. 


\begin{tabular}{lccccccc}
\hline Season & $\begin{array}{c}\text { Type of } \\
\text { locality }\end{array}$ & $\begin{array}{c}\text { Number } \\
\text { rodent } \\
\text { collected }\end{array}$ & $\begin{array}{c}\text { \% Prevalence of } \\
\text { fleas }(95 \% \mathrm{Cl})\end{array}$ & $\begin{array}{c}\text { Intensity mean } \\
(95 \% \mathrm{Cl})\end{array}$ & $\begin{array}{c}\text { Number } \\
\text { fleas } \\
\text { analyzed }\end{array}$ & $\begin{array}{c}\text { Number of } \\
\text { fleas } \\
\text { positive to } \\
\text { gltA }(\%)\end{array}$ & $\begin{array}{c}\text { Number of } \\
\text { fleas } \\
\text { positive }\end{array}$ \\
\hline \multirow{6}{*}{ Winter } & City & 59 & $28.81(0.18-0.42)$ & $3.06(2.12-4.13)$ & 49 & $9(18.36)$ & $6(12.24)$ \\
& Village & 19 & $57.89(0.33-0.80)$ & $3.09(2.27-3-91)$ & 33 & $15(45.45)$ & $6(18.18)$ \\
& Wild area & 44 & $31.80(0.19-0.47)$ & $1.77(1.00-2.57)$ & 17 & $2(11.76)$ & $3(17.65)$ \\
& Total & 122 & $34.43(0.26-0.43)$ & $2.62(2.10-3.31)$ & 99 & $26(26.26)$ & $15(15.15)$ \\
\multirow{6}{*}{ Summer } & City & 90 & $24.44(0.16-0.35)$ & $1.64(1.27-2.23)$ & 32 & $3(9.37)$ & $3(9.37)$ \\
& Village & 34 & $38.20(0.22-0.56)$ & $2.62(1.77-3.62)$ & 33 & $8(24.24)$ & $15(44.45)$ \\
& Wild area & 15 & $26.67(0.08-0.55)$ & $2.50(1.00-3.00)$ & 10 & 0 & $1(10)$ \\
& Total & 139 & $28.06(0.21-0.36)$ & $2.05(1.64-2.49)$ & 75 & $11(14.67)$ & $19(25.33)$ \\
\hline
\end{tabular}

1 


\section{Table 5 (on next page)}

Bartonella species detected with BLAST using concatenated glt $A$ and $r p o B$ genes, in the identified flea species collected in Chile. 


\begin{tabular}{|c|c|c|c|c|}
\hline Flea species & Bartonella species isolated & $\begin{array}{c}\text { BLAST } \\
\text { Sequence } \\
\text { similarity }(\%)\end{array}$ & $\begin{array}{c}\text { GenBank } \\
\text { accession number }\end{array}$ & $\begin{array}{c}\text { Locality / Hydrographic } \\
\text { zone }\end{array}$ \\
\hline \multirow[t]{2}{*}{ Xenopsylla cheopis } & Bartonella sp. B28297 & 100 & KM233489.1 & Iquique/ Hyper-arid \\
\hline & Bartonella mastomydis & 100 & KY555066.1 & Iquique/ Hyper-arid \\
\hline Leptopsylla segnis & Bartonella sp. 16/40 & 97 & AY584859.1 & Sotaquí / Arid \\
\hline \multirow[t]{2}{*}{ Nosopsyllus fasciatus } & Bartonella sp. 16/40 & 97 & AY584859.1 & Sotaquí / Arid \\
\hline & Bartonella tribocorum & 100 & HG969192.1 & $\begin{array}{l}\text { Puerto Aysén / Hyper- } \\
\text { humid }\end{array}$ \\
\hline Hectopsylla sp. & Bartonella sp. 16/40 & 96 & AY584859.1 & Sotaquí / Arid \\
\hline Neotyphloceras chilensis & Bartonella sp. (strain C1phy) & 99 & Z70022.1 & Canela Baja /Arid \\
\hline Neotyphloceras pardinasi & Bartonella sp. (strain C1phy) & 99 & Z70022.1 & Canela Baja /Arid \\
\hline Sphinctopsylla ares & $\begin{array}{c}\text { Uncultured Bartonella sp. clone } \\
\text { LBCE } 10781\end{array}$ & 95 & KX270236.1 & Nonguén/ Sub-humid \\
\hline
\end{tabular}

